IZA DP No. 8142

Does High School Homework Increase Academic Achievement?

Charlene Marie Kalenkoski

Sabrina Wulff Pabilonia

April 2014 


\title{
Does High School Homework Increase Academic Achievement?
}

\author{
Charlene Marie Kalenkoski \\ Texas Tech University \\ and IZA
Sabrina Wulff Pabilonia
U.S. Bureau of Labor Statistics
and IZA

Discussion Paper No. 8142

April 2014

IZA
P.O. Box 7240
53072 Bonn
Germany

Phone: +49-228-3894-0

Fax: +49-228-3894-180

E-mail: iza@iza.org

\begin{abstract}
Any opinions expressed here are those of the author(s) and not those of IZA. Research published in this series may include views on policy, but the institute itself takes no institutional policy positions. The IZA research network is committed to the IZA Guiding Principles of Research Integrity.

The Institute for the Study of Labor (IZA) in Bonn is a local and virtual international research center and a place of communication between science, politics and business. IZA is an independent nonprofit organization supported by Deutsche Post Foundation. The center is associated with the University of Bonn and offers a stimulating research environment through its international network, workshops and conferences, data service, project support, research visits and doctoral program. IZA engages in (i) original and internationally competitive research in all fields of labor economics, (ii) development of policy concepts, and (iii) dissemination of research results and concepts to the interested public.
\end{abstract}

IZA Discussion Papers often represent preliminary work and are circulated to encourage discussion. Citation of such a paper should account for its provisional character. A revised version may be available directly from the author. 


\section{ABSTRACT}

\section{Does High School Homework Increase Academic Achievement?*}

Although previous research has shown that homework improves students' academic achievement, the majority of these studies use data on students' homework time from retrospective questionnaires, which are less accurate than time-diary data. However, most time-diary data sets do not contain outcome measures, and thus are limited in the questions they can answer. One data set that does have both time-diary and outcome information is the combined Child Development Supplement (CDS) and the Transition to Adulthood Survey (TA) of the Panel Study of Income Dynamics. Students complete time diaries as part of the CDS and then a few years later provide information on outcomes in the TA. The CDS provides us with time diaries for both weekdays and weekend days, providing a good picture of homework over the course of a week rather than on just a single day. For high school graduates, we explore the effects of time spent on homework on two measures of academic achievement: high school GPA and college attendance by age 20. We find that homework time increases the probability of college attendance for boys. In addition, when we look at homework performed as a sole activity, we find that homework increases high school GPA for boys.

JEL Classification: $\quad$ 12, J22, J24

Keywords: academic achievement, homework, GPA, human capital, education

Corresponding author:

Charlene M. Kalenkoski

Department of Personal Financial Planning

Texas Tech University

Human Sciences Room 242

1301 Akron Avenue

Box 41210

Lubbock, TX 79409-1210

USA

E-mail: charlene.kalenkoski@ttu.edu

\footnotetext{
* All views expressed in this paper are those of the authors and do not necessarily reflect the views or policies of the U.S. Bureau of Labor Statistics or United States. The authors thank Andrew Bibler, Debanik Das, Xiuming Jin, and Xi Mao for research assistance and Elisabeth Handwerker, Jennifer Imazeki, Daniel Rees, and Jay Stewart for comments. The collection of the PSID-CDS data used in this study was partly supported by the National Institutes of Health under grant number R01 HD069609 and the National Science Foundation under award number 1157698.
} 


\section{Introduction}

Economic studies have shown that homework completed by or assigned to high school students improves their performance on math tests (Betts, 1996; Aksoy \& Link, 2000; Eren \& Henderson, 2008). Studies of middle school students (Eren and Henderson, 2011) and college students (Stinebrickner \& Stinebrickner, 2008; Grodner \& Rupp, 2013) have found that homework similarly improves students' performance on math and other tests and first-semester grade point averages (GPA). ${ }^{1}$ However, the majority of these studies are based on retrospective questionnaire data that provide information about assigned or completed homework during a typical week, which may not be very accurate and also may be subject to social desirability bias. Time-diary data, on the other hand, are more accurate because of a shorter recall period and are not subject to social desirability bias because they are collected for all activities over an entire 24-hour period rather than just specific activities (Juster, Ono, \& Stafford, 2003). In addition, time-diary data may be more detailed than questionnaire data as they often capture the presence of secondary activities (i.e., activities performed at the same time as a reported main activity) that the usual survey questions do not.

Unfortunately, most time-diary data sets do not contain information on the future outcomes of those completing the diaries and thus are limited in the questions they can answer. ${ }^{2}$ One data set that does have both homework and outcome information, however, is the combined

\footnotetext{
${ }^{1}$ Cooper, Robinson, and Patall (2006) provide a nice overview of the effects of homework on academic achievement in the education, psychology, and sociology literatures. In general, small positive effects have been found. However, most researchers have performed only simple analyses. More recently, using 1990 data from National Education Longitudinal Study (NELS) and 2002 data from Education Longitudinal Study (ELS), Maltese, Tai, and Fan (2012) found no effect of math and science homework on final course grades, but a significant positive association between homework time and the SAT-Mathematics subscore.

${ }^{2}$ Stinebrickner and Stinebrickner (2008) is the exception that uses time-diary data to examine outcomes. However, their sample is a small, non-representative one. They sample students from one college only.
} 
Child Development Supplement to the Panel Study of Income Dynamics (PSID-CDS) and its follow-up, the Transition to Adulthood Study (TA). Students participate in the TA a few years after participating in the CDS. The CDS data provide information from two time diaries, one for a weekday and the other for a weekend day, providing a picture of homework over the course of a week. The CDS data also provide scores on students' standardized tests taken before high school, which we use to control for students' ability and thus minimize the potential for omitted variable bias. The TA data provide information on high school GPA and college attendance.

We measure homework time in three ways in order to account for the fact that multitasked homework time may be less productive than sole-tasked homework. We use total homework time (homework performed as either a primary or secondary activity), time spent doing homework as a primary activity, and time spent doing homework as a sole activity. Using the cmp command in Stata, we estimate the effects of time spent on homework using each of these measures on high school GPA and college attendance, both long-term measures of academic achievement. We examine whether these effects differ by gender, given substantial differences in how girls and boys spend their time. We find that homework time by any measure increases the probability of college attendance by age 20 for boys. We also find that homework as a sole activity has a small positive association with high school GPA for boys. When we account for the potential endogeneity of homework, however, these effects become statistically insignificant.

\section{Data}

The data used in our analyses primarily come from the first, second, and third CDS (1997, 2002-2003, 2007-2008) and the first, second, third, and fourth TA (2005, 2007, 2009, and 
2011). Information about children aged 0-12 first was collected in the 1997 CDS (CDS1) and additional information about them was collected in the 2002-2003 CDS (CDS2) when they were aged 5-19 and in the 2007-2008 CDS (CDS3) when they were aged 10-19. Even more information about former CDS respondents is provided in the TA for those aged 18 and older at the time of that survey. The CDS1 provides background information on the parent/caregiver of the CDS child as well as information on the child's race. The CDS2 and CDS3 provide timediary information for a weekday and a weekend day for a subset of CDS children, with diaries collected for up to two children per family. Each randomly-assigned diary day records the child's primary and secondary activities from midnight to midnight. By the time the child was in high school, most filled out the diaries themselves instead of the parent. The TAs provide information on high school GPA and college attendance for high school graduates. We obtain information on each child's gender, family structure, parental education, and family income from the main PSID survey. ${ }^{3}$ We also control for school-level characteristics by matching our sample to the NCES' Common Core of Data (CCD) using school identifiers from the restricted-use version of the PSID-CDS. We use data from the National Climate Data Center (NCDC) of the National Oceanic and Atmospheric Administration (NOAA) on daily precipitation to help identify homework time in regressions where we control for potential endogeneity. Daily precipitation is matched to our sample using county-level identifiers from the restricted-use version of the PSID-CDS.

\footnotetext{
${ }^{3}$ Our measure of family income comes from the main PSID interviews. It is constructed to be the average of yearly family income reported in the three PSID main interviews prior to completing the CDS high school diary, in 2006 dollars. If one or more years is missing, then the remaining values are used to create the average. Family structure and parental education are obtained from 2003 and 2007 main PSID surveys.
} 
We limit our sample to high school graduates who were enrolled in grades 9 through 12 in CDS2 or CDS3. ${ }^{4}$ We further exclude those who did not complete both a weekday and a weekend day diary, those who completed their time diaries over winter break or on any day in June when they did not attend school, ${ }^{5}$ those who were missing the child interview in 2007, those who were missing information on race, one respondent whose family income was negative, those who were missing TA information on college attendance by age 20, those who were missing a diary date, those who attended private school, those who were missing a 2003 main family interview, those who were missing school-level variables, and a few who were missing weather data. This leaves us with an analysis sample of 805 respondents that includes 438 females and 367 males. $^{6}$

Our measures of academic achievement are a continuous measure for high school GPA that ranges from 0 to $100^{7}$ and an indicator variable for college attendance by age 20. College attendance by age 20 is equal to 1 if a respondent attended college before the month of his or her $20^{\text {th }}$ birthday and 0 otherwise. $^{8}$

Our key explanatory variables are total weekly hours spent doing homework, weekly hours spent doing homework as a primary activity, and weekly hours spent doing homework as a

\footnotetext{
${ }^{4}$ High school GPA and information on college attendance are available only for high school graduates. In the PSID-CDS, ninety-two percent of high school students graduated, which is close to that reported by the U.S. Department of Education (2013) for 2011.

${ }^{5}$ We defined winter break to be an approximately two-week period around Christmas and New Year's Day.

${ }^{6}$ See Appendix Table A1 for further details on sample construction.

${ }^{7}$ GPA scales vary by school. Because we have only the reported GPA and the maximum possible GPA for each observation, we created this variable by dividing the reported GPA by the maximum possible and multiplying by 100 .

${ }^{8}$ In each TA, the student reported the first enrollment date for "current / last college attended" and then the first enrollment date for one additional prior college attended. We compare the first reported enrollment date in months with the month that the student would have turned age 20 to determine college attendance by age 20.
} 
sole activity. Total homework time includes time spent on homework, regardless of whether it was reported to be the main activity. Primary homework time may be a measure of higher quality homework time because it only includes homework time when homework is reported as the main (or viewed by the student as the most important) activity. Time spent doing homework as a sole activity may be an even higher measure of quality homework because it captures homework time when homework is the only activity being performed. One study by Rosen, Carrier, and Cheever (2013) found that those who checked Facebook while studying had lower GPAs.

Because we have only two days of time-diary information, one weekday and one weekend day, we constructed each of our weekly homework measures by multiplying the weekday time spent by 5 , multiplying the weekend day time spent by 2 , and then adding these two products together, as in Hofferth (2010). ${ }^{9}$ All three homework measures include the following activity codes: 5040 (using a computer for homework, studying, or research), 5192 (being tutored), 5490 (general homework/studying), 5491 (non-computer-related homework), 5492 (studying, research, reading related to classes, or working on school project), 5493 ("Went to library”), and 5494 (reviewing homework with a parent/caregiver). Common secondary activities performed while doing homework were listening to music, and watching TV. Our measures do not capture homework done while in class.

We control for a rich set of individual, family, and school characteristics. Our individual controls include indicators for being female, being black or Hispanic, the Census region of

\footnotetext{
${ }^{9}$ Given that we are interested in examining the effect of time spent on homework during a student's high school career on future outcomes, our time use variables, which are based on two diary days, may be measured with error. Thus, our estimated effects would be biased toward zero. However, this criticism applies to many survey data questions as well. Our models that control for the potential endogeneity of homework also correct for this.
} 
residence in high school, and a set of year dummies indicating the year prior to the student graduating high school. The year dummies control for the fact that students are interviewed in different grades and in different periods. ${ }^{10}$ We also control for whether a student was living in a state that required all high school students to take a college entrance exam as this could affect students’ motivation. To control for ability, we include age-adjusted broad-reading and appliedproblems standardized test scores from the Woodcock-Johnson Revised Tests of Basic Achievement (WJ-R). ${ }^{11}$ These scores are from the CDS interview occurring five years prior to the CDS high school interview and are more likely to measure inherent ability than tests administered during high school.

We control for several family characteristics, including the number of other household children under age 20, average real family income over the five years prior to the time diary and its square, and indicators for whether the mother has a college degree, mother's degree is missing, whether the student lives with a single mother, and whether the student lives in some other family arrangement that was not a two-parent family. ${ }^{12}$ We also control for three schoollevel characteristics: the fraction of the respondent's high school that was white (averaged over the respondent's high school years ${ }^{13}$, the fraction of the respondent's high school that was freeor reduced-price-lunch eligible (also an average over the respondent's high school years), and the respondent's high school's student-teacher ratio (also an average over the respondent's high

\footnotetext{
${ }^{10}$ Some years had to be combined in order to achieve convergence - specifically, 2002 was combined with 2003, 2007 was combined with 2008, and 2009 was combined with 2010.

${ }^{11}$ We also include an indicator for missing scores and assign the average score to those missing scores.

${ }^{12}$ Parents in two-parent families could be biological, adoptive, or step parents.

${ }^{13}$ If a year is missing, then the average over the non-missing years is used.
} 
school years). ${ }^{14}$ Several additional variables are used as exclusion restrictions to identify homework in the outcome equations. ${ }^{16}$ In the female specifications, these include indicators for whether the weekday diary day was a Friday and whether the diary was in a spring month, and average precipitation in the county of residence on the weekday diary day. ${ }^{17}$ In the male specifications, these include indicators for whether the weekday diary day was a Friday, whether the weekend diary day was a Saturday, and whether the student was older than the state minimum driving age at the time of the weekday diary. While these exclusion restrictions are expected to affect how much time was spent on homework on the diary day, they should otherwise be uncorrelated with high school GPA and college attendance.

\section{Descriptive Statistics}

Table 1 provides the weighted means for all variables used in the analyses and the standard deviations for the continuous variables. The outcome variables are presented first. In our sample of 805 high school graduates, the average high-school GPA was 83 out of 100 for

\footnotetext{
${ }^{14}$ The student-teacher ratio in each year is the total number of students in the school divided by full-time-equivalent classroom teachers.

${ }^{15}$ We also include an indicator for missing school variables due to a missing school-level identifier in the PSID-CDS. We assign the average of the non-missing values to those missing a value.

${ }^{16}$ In order to minimize the potential for a "weak instruments" problem, the exclusion restriction sets differ by gender because they differ in the strength of their correlation with homework time. ${ }^{17}$ Daily weather data was obtained from all stations in the Cooperative Observer Network (COOP), Weather Bureau Army Navy (WBAN), and World Meteorological Organization (WMO) networks and averaged across each county by day. For about 30 observations, the county value was missing, so a neighboring county's value was substituted for the missing value. This weather data is available from ftp://ftp.ncdc.noaa.gov/pub/data/ghcn/daily/. We find that precipitation on the diary day matters only for girls' homework activities. Similarly, Connolly (2013) found that only girls' life satisfaction was lower on rainy days.
} 
girls and 78 out of 100 for boys. Ninety percent of girls who graduated from high school enrolled in college by the age of 20 while only 87 percent of boys enrolled.

Next, the explanatory variables are presented. On average, girls engaged in 7.6 hours of total homework (primary plus secondary) over the course of a week while boys averaged 5.2 hours. ${ }^{18}$ These means may surprise some, given a popular belief that children today are assigned too much homework (Lahey, 2012). ${ }^{19}$ However, these weekly averages are not that different from retrospective questions on homework per week in recent history. For example, using the National Education Longitudinal Study of 1988 (NELS), McMullen (2011) found that $10^{\text {th }}$ graders in 1990 did about 8 hours of homework per week and $12^{\text {th }}$ graders in 1992 did about 14 hours of homework per week, including homework that they did while in school. ${ }^{20}$ According to the Higher Education Research Institute at UCLA (Loveless 2014), only 33 percent of college freshman in 2002 reported spending six or more hours per week doing homework in their senior year.

The average for homework as a primary activity is, of course, smaller than that for total homework because it does not include homework performed as a secondary activity, but girls

\footnotetext{
${ }^{18}$ Over the course of the two observed diary days, 72 percent of females did some homework while in high school but ostensibly outside school hours while only 60 percent of males did some homework. These figures are consistent with measures from other time use data from the American Time Use Survey (ATUS). Kalenkoski and Pabilonia (2012) found that on any given school day only 51 percent of teenagers aged 15-18 did some homework, while on any given non-school day only 29 percent of teenagers did some homework. In addition, according to the 2008 National Assessment of Educational Progress (NAEP) (Loveless, 2014), about 28 percent of all seventeen year olds were not assigned any homework and another 12 percent did not do their homework the day before. Loveless (2014) also shows that over the 1984-2012 period 17 year olds did not significantly change the amount of homework they did. In addition, in 2004, 12 percent of 17-year-old respondents to the NAEP reported doing no homework on a "usual" day while another 12 percent reported doing more than two hours.

${ }^{19}$ See Eren and Henderson (2011) for a review of the historical debate about the merits of assigning homework over the last century.

${ }^{20}$ These weekly homework averages were calculated from a series of categories.
} 
still have a higher average than boys ( 7 hours versus 5 hours). The results also show that students often are doing other things while doing their homework. Time spent doing homework as a sole activity is roughly half the amount of total homework time, with an average of 3.59 hours for girls and 2.45 hours for boys.

Table 2 shows differences in hours spent on homework between those earning above- and below-average GPA and between those attending or not attending college by age 20. Panel A shows the results using the total homework measure, Panel B shows the results using the homework as a primary activity measure, and Panel C shows the results using the homework as a sole activity measure. Regardless of measure, those with above-average GPAs did more homework, on average, than those with below-average GPAs, although the differences are never statistically significant. Boys who attended college did $3 \frac{1}{4}$ hours more homework than those who did not. Differences in average homework time were not statistically significant for girls, although those who attended college did more than those who did not.

\section{Econometric Analyses}

For high school GPA, we first estimate the following linear regression model using Ordinary Least Squares (OLS):

$$
\mathrm{Z}=\mathrm{b}_{0}+\mathrm{b}_{1} * \mathrm{H}+\mathrm{b}_{2} * \mathrm{X}+\mathrm{u}
$$

where $\mathrm{Z}$ represents high school GPA; $\mathrm{b}_{0}, \mathrm{~b}_{1}$, and $\mathrm{b}_{2}$ are the coefficients to be estimated; $\mathrm{H}$ is a measure of time spent on homework, $\mathrm{X}$ is the matrix of control variables, and $\mathrm{u}$ is a normally- 
distributed error term. The subscripts indicating observation are suppressed. For college attendance, which is a discrete outcome, we estimate a probit model via maximum likelihood:

$$
\begin{array}{r}
\mathrm{Y}^{*}=\mathrm{a}_{0}+\mathrm{a}_{1} * \mathrm{H}+\mathrm{a}_{2} \mathrm{X}+\mathrm{e} \\
\mathrm{Y}=1 \text { if } \mathrm{Y}^{*}>0 \\
\mathrm{Y}=0 \text { otherwise }
\end{array}
$$

where $\mathrm{Y}^{*}$ is the latent variable representing the net benefit of attending college; $\mathrm{Y}$ is the observed outcome; $\mathrm{a}_{0}, \mathrm{a}_{1}$, and $\mathrm{a}_{2}$ are the coefficients to be estimated; and $\mathrm{e}$ is a normallydistributed error term. As in (1), the subscripts indicating observation are suppressed.

Table 3 shows the effects of the different continuous homework measures on student achievement. ${ }^{21}$ Panel A shows the results for the total homework measure, Panel B shows the results for the homework as a primary activity measure, and Panel C shows the results for the homework as a sole activity measure. In each panel, Columns 1-2 report results from the GPA regressions for the female and male subsamples respectively. Columns 3-4 report the results from the college attendance models for the female and male subsamples respectively. For the college attendance probits, we report the average marginal effects and their standard errors. All

\footnotetext{
${ }^{21}$ Results for the other marginal effects in these models are in Appendix Tables A2 and A3. For females, the applied-problems score has a positive significant effect on GPA and living in a family arrangement other than a two-parent family has a negative significant effect on GPA. For males, having a mother with a college degree and the fraction free-or-reduced-price-lunch eligible in high school have positive significant effects on GPA. For females, being black or Hispanic, the reading score, the applied-problems score, living in a state that mandates a college exam, the number of household children, having a mother with a college degree, and household income all have positive effects on attending college by age 20. For males, the applied-problems score and living in a state that mandates a college exam have positive effects on college by age 20 while the fraction free-or-reduced-price-lunch eligible in high school has a negative significant effect on attending college by age 20 .
} 
estimates are weighted using survey weights and standard errors are adjusted for clustering on state because we include some state-level regressors (Cameron \& Miller, 2014).

We find a significant positive relationship between homework and college attendance by age 20 for males, regardless of homework measure. The magnitude of the effect is also economically significant. An extra hour of total homework per night (i.e. 7 hours per week) would increase the probability of attendance by nearly 5 percentage points. We also find that homework measured as a sole activity is related positively to GPA for males. The effects of homework as a sole activity on GPA are quite small, however, with the effects of an increase in homework on GPA by one hour per night being about 2.5 percentage points on a scale of 100 for males.

We next consider the possibility that homework time is endogenous. Although teachers assign a certain amount of homework, students choose their level of effort, which may depend on an unobserved factor such as motivation, which also affects academic achievement directly. ${ }^{22}$ We therefore add the following homework equation to each of the previous models.

$$
\mathrm{H}=\mathrm{d}_{0}+\mathrm{d}_{1} \mathrm{X}+\mathrm{d}_{2} \mathrm{~W}+\gamma
$$

where $\mathrm{W}$ includes three variables that identify homework in the outcome equation. ${ }^{23}$ In the female specifications, these are an indicator for whether the weekday diary day was a Friday, an indicator for whether the diary was in a spring month, and average daily precipitation in the

\footnotetext{
${ }^{22}$ We did include test scores to control for ability and we do find that their inclusion slightly decreases the magnitude of the effects in the OLS specifications (results available upon request). ${ }^{23}$ We also estimated a Tobit model for homework as there are a fair number of students who do not report doing any homework (see Appendix Table A8) and some studies (Kalenkoski \& Pabilonia, 2012) have used Tobits to estimate homework equations. In these specifications, we continue to find no significant effects of homework on academic achievement.
} 
county of residence on the weekday diary day. In the male specifications, these are indicators for whether the weekday diary day was a Friday, whether the weekend diary day was a Saturday, and whether the student was older than the state minimum driving age. $d_{0}, d_{1}$ and $d_{2}$ are the coefficients to be estimated and $\gamma$ is an error term. Joint estimation of the outcome equation (either (1) or (2)) and the homework equation (3) is achieved via limited information maximum likelihood using the cmp command in Stata and assumes the error terms in the outcome and homework equations are jointly normally distributed.

Table 4 presents results that control for endogeneity. ${ }^{24}$ We find that homework is no longer a significant predictor of college attendance by age 20 for males. In most cases, the excluded variables are individually significant at the $1 \%$ or $5 \%$ level. However, the estimated correlation coefficients between the error terms across equations are never significant at the $5 \%$ level (only one is marginally significant at the $10 \%$ level). In addition, Wooldridge endogeneity tests performed using unreported results from a 2SLS model for the GPA specifications fail to reject the hypothesis that homework is exogenous in the GPA equations. Stata does not allow endogeneity tests after running ivprobit. Therefore, we do not perform endogeneity tests for homework in the college attendance by age 20 probits that allow homework to be endogenous. Standard tests of over-identifying restrictions are invalid with cluster robust standard errors and thus also were not performed.

\footnotetext{
${ }^{24}$ Results for the other coefficients in these models are available in Appendix Tables A4-A7. In the GPA regressions (Table A4), we find that living with a mother who has a college degree, being female, the WJ-R applied problems test scores, and the fraction who are eligible for freeor-reduced-price-lunch have positive effects. In the college attendance regressions (Table A5), being female, being black or Hispanic, WJ-R broad reading scores and applied problems test scores, family income, and living with a mother who has a college degree all positively increase the probability of attendance. In the first-stage homework regressions, family income positively affects time spent on homework. First-stage regression estimates are given in Appendix Tables A6 and A7.
} 


\section{Conclusion}

In this paper, we examine the effects of high school homework time on two academic outcomes, high school GPA and college attendance by age 20, using time-diary data, which are more accurate than data from retrospective survey questions. We control for a rich set of variables that includes students’ characteristics, such as early test scores to control for ability, family variables, and school-level characteristics. We find that homework as a sole activity has a small positive significant effect on GPA for males only. We also find that homework has a statistically and economically significant positive effect on the probability of attending college by age 20 for males; however, these results become insignificant when we control for potential endogeneity. However, exogeneity tests performed for homework in the GPA regressions suggest that the results that find a positive effect of homework on GPA for boys are the preferred results. Additionally, the estimated correlation coefficients in both the GPA and college attendance models are never statistically significant at the $5 \%$ level, suggesting that the results that treat homework as exogenous are preferred in both the GPA and college attendance models. Based on these specifications, we conclude that an increase in homework time may increase the high school GPAs and the probability of college attendance of high school boys. 


\section{References}

Aksoy, Tevfik and Charles R. Link. (2000). “A Panel Analysis of Student Mathematics Achievement in the US in the 1990s: Does Increasing the Amount of Time in Learning Activities Affect Math Achievement?” Economics of Education Review 19: 261-277.

Betts, Julian R. (1996). “The Role of Homework in Improving School Quality.” Discussion Paper 96-16, Department of Economics, University of California, San Diego.

Cameron, A. Colin and Douglas L. Miller. (2013). “A Practitioner’s Guide to Cluster-Robust Inference.” Forthcoming in Journal of Human Resources.

Cooper, Harris, Jorgianne Civey Robinson, and Erika A. Patall. (2006). "Does Homework Improve Academic Achievement? A Synthesis of Research, 1987-2003." Review of Educational Research 76(1): 1-62.

Connolly, Marie. (2013). "Some Like It Mild and Not Too We: The Influence of Weather on Subjective Well-Being.” Journal of Happiness Studies 14: 457-473.

Eren, Ozkan and Daniel J. Henderson. (2008). “The Impact of Homework on Student Achievement.” Econometrics Journal 11: 326-348.

Eren, Ozkan and Daniel J. Henderson. (2011). “Are We Wasting Our Children’s Time By Giving Them More Homework?” Economics of Education Review 30(5): 950-961.

Grodner, Andrew and Nicholas G. Rupp. (2013). "The Role of Homework on Student Learning Outcomes: Evidence from a Field Experiment.” Journal of Economic Education 44(2): 93-109.

Heckman, James J., John Eric Humphries, and Nicholas S. Mader. (2011). “The GED.” In Eric A. Hanushek, Stephen J. Machin, and Ludger Woessmann (eds.), Handbook of the Economics of Education, Volume 3 (pp. 423-484). Amsterdam: North-Holland.

Hofferth, Sandra L. (2010). “Home Media and Children’s Achievement and Behavior.” Child Development 81(5): 1598-1619.

Juster, F. Thomas, Hiromi Ono, and Frank P. Stafford. (2003). “An Assessment of Alternative Measures of Time Use.” Sociological Methodology 33: 19-54.

Kalenkoski, Charlene Marie and Sabrina Wulff Pabilonia. (2012). “Time to Work or Time to Play: The Effect of Student Employment on Homework, Sleep, and Screen Time.” Labour Economics 19(2): 211-221.

Lahey, Jessica. (2012). “The Destructive ‘Too Much Homework’ Myth.” New York Times 3/6/12 http://parenting.blogs.nytimes.com/2012/03/06/the-destructive-too-muchhomework-myth/ 
Loveless, Tom. (2014). "How Well Are American Students Learning? With Special Sections on the PISA-Shanghai Controversy, Homework, and the Common Core.” Brown Center Report on American Education 3(3), Washington, DC: The Brookings Institution.

Maltese, Adam V., Robert H. Tai, and Xitao Fan. (2012). "When is Homework Worth the Time? Evaluating the Association Between Homework and Achievement in High School Science and Math.” The High School Journal 96(1): 52-72.

McMullen, Steven. (2011). "How do Students Respond to Labor Market and Education Incentives? An Analysis of Homework Time.” Journal of Labor Research 32: 199-209.

Panel Study of Income Dynamics, restricted use data. Produced and distributed by the Survey Research Center, Institute for Social Research, University of Michigan, Ann Arbor, MI 2009-2013.

Roodman, David. (2011). "Fitting Fully Observed Recursive Mixed-process Models with cmp.” The Stata Journal 11(2): 159-206.

Rosen, Larry D., L. Mark Carrier, \& Nancy A. Cheever. (2013). "Facebook and Texting Made Me Do It: Media-induced Task-Switching While Studying.” Computers in Human Behavior 29:948-958.

Stinebrickner, Ralph and Todd R. Stinebrickner. (2008). "The Causal Effect of Studying on Academic Performance.” The B.E. Journal of Economic Analysis \& Policy 8(1) (Frontiers), Article 14.

U.S. Department of Education, National Center for Education Statistics. (2013). The Condition of Education 2013 (NCES 2013-037), Indicator 29. 


\begin{tabular}{|c|c|c|c|c|}
\hline & \multicolumn{2}{|c|}{$\begin{array}{l}\text { Females } \\
(\mathrm{N}=438)\end{array}$} & \multicolumn{2}{|c|}{$\begin{array}{c}\text { Males } \\
(\mathrm{N}=367)\end{array}$} \\
\hline & Mean & S.D. & Mean & S.D. \\
\hline \multicolumn{5}{|l|}{ Dependent Variables } \\
\hline High-school GPA (percent) (high-school graduates only) & 83.49 & 11.29 & 78.32 & 13.14 \\
\hline College attendance by age 20 & 0.90 & & 0.87 & \\
\hline \multicolumn{5}{|l|}{ Individual Control Variables } \\
\hline Total homework (primary + secondary activity) & 7.55 & 7.96 & 5.21 & 7.71 \\
\hline Homework as a primary activity & 7.01 & 7.77 & 4.99 & 7.48 \\
\hline Homework as a sole activity & 3.59 & 5.80 & 2.45 & 4.31 \\
\hline Black/Hispanic ethnicity & 0.29 & & 0.28 & \\
\hline WJ-R broad-reading score 5 years before HS & 109.04 & 15.80 & 108.34 & 15.84 \\
\hline WJ-R applied-problems score 5 years before HS & 108.61 & 14.18 & 113.94 & 15.74 \\
\hline Missing a WJ-R score & 0.12 & & 0.14 & \\
\hline Lived in North Central region in HS & 0.25 & & 0.22 & \\
\hline Lived in South region in HS & 0.32 & & 0.28 & \\
\hline Lived in West region in HS & 0.29 & & 0.35 & \\
\hline Year before graduate HS - 2002/2003 & 0.24 & & 0.26 & \\
\hline Year before graduate HS - 2004 & 0.13 & & 0.11 & \\
\hline Year before graduate HS - 2005 & 0.13 & & 0.14 & \\
\hline Year before graduate HS - 2007/2008 & 0.27 & & 0.26 & \\
\hline State-mandated college entrance exam & 0.08 & & 0.08 & \\
\hline \multicolumn{5}{|l|}{ Family Control Variables } \\
\hline Single mother & 0.21 & & 0.20 & \\
\hline Other family arrangement & 0.03 & & 0.06 & \\
\hline Number of other household children < age 20 & 1.21 & 1.15 & 1.04 & 1.04 \\
\hline Mother college degree (non-missing) & 0.29 & & 0.26 & \\
\hline Mother education missing & 0.06 & & 0.10 & \\
\hline $\begin{array}{l}\text { Average real family income over last } 5 \text { years (in } 2006 \\
\$ 1,000 \text { s) }\end{array}$ & 97.59 & 100.99 & 100.93 & 130.95 \\
\hline \multicolumn{5}{|l|}{ School-level Control Variables } \\
\hline Fraction white (average while in high school) & 0.61 & & 0.63 & \\
\hline $\begin{array}{l}\text { Fraction free-or-reduced-price lunch (average while in } \\
\text { high school) }\end{array}$ & 0.37 & & 0.38 & \\
\hline Student-teacher ratio (average while in high school) & 17.83 & 4.49 & 17.67 & 5.27 \\
\hline Missing school & 0.09 & & 0.07 & \\
\hline \multicolumn{5}{|l|}{ Instruments } \\
\hline Friday diary & 0.20 & & 0.18 & \\
\hline Saturday diary & 0.47 & & 0.50 & \\
\hline Older than state minimum driving age & 0.53 & & 0.58 & \\
\hline Weekday precipitation (in mm) & 21.97 & 51.27 & 26.76 & 64.01 \\
\hline Spring interview & 0.10 & & 0.09 & \\
\hline
\end{tabular}

Note: These results use CDS child weights. 
Table 2. Differences in Hours Spent on Homework by GPA and College Attendance by Age 20

Panel A. Total Homework

\begin{tabular}{|c|c|c|c|c|c|c|c|c|}
\hline & $\begin{array}{l}\text { Above- } \\
\text { Average GPA }\end{array}$ & $\begin{array}{l}\text { Below- } \\
\text { Average GPA }\end{array}$ & Difference & P-value & $\begin{array}{l}\text { Attend } \\
\text { College }\end{array}$ & $\begin{array}{l}\text { Not Attend } \\
\text { College }\end{array}$ & Difference & $\mathrm{P}$-value \\
\hline Female & $\begin{array}{l}7.84 \\
(7.32)\end{array}$ & $\begin{array}{l}7.22 \\
(8.64)\end{array}$ & 0.62 & 0.53 & $\begin{array}{l}7.65 \\
(7.95)\end{array}$ & $\begin{array}{l}6.66 \\
(7.69)\end{array}$ & 0.99 & 0.47 \\
\hline Male & $\begin{array}{l}5.58 \\
(7.26)\end{array}$ & $\begin{array}{l}4.83 \\
(8.01)\end{array}$ & 0.75 & 0.50 & $\begin{array}{l}5.62 \\
(7.80)\end{array}$ & $\begin{array}{l}2.37 \\
(4.15)\end{array}$ & 3.25 & 0.00 \\
\hline
\end{tabular}

Panel B. Homework as a Primary Activity

\begin{tabular}{|c|c|c|c|c|c|c|c|c|}
\hline & $\begin{array}{l}\text { Above- } \\
\text { Average GPA }\end{array}$ & $\begin{array}{l}\text { Below- } \\
\text { Average GPA }\end{array}$ & Difference & P-value & $\begin{array}{l}\text { Attend } \\
\text { College }\end{array}$ & $\begin{array}{l}\text { Not Attend } \\
\text { College }\end{array}$ & Difference & P-value \\
\hline Female & $\begin{array}{l}7.40 \\
(7.415)\end{array}$ & $\begin{array}{l}6.57 \\
(8.44)\end{array}$ & 0.83 & 0.38 & $\begin{array}{l}7.10 \\
(7.81)\end{array}$ & $\begin{array}{l}6.20 \\
(7.02)\end{array}$ & 0.90 & 0.46 \\
\hline Male & $\begin{array}{l}5.25 \\
(6.87)\end{array}$ & $\begin{array}{l}4.88 \\
(7.97)\end{array}$ & 0.37 & 0.63 & $\begin{array}{l}5.37 \\
(7.57)\end{array}$ & $\begin{array}{l}2.37 \\
(4.15)\end{array}$ & 3.00 & 0.00 \\
\hline
\end{tabular}

Panel C. Homework as a Sole Activity

\begin{tabular}{|c|c|c|c|c|c|c|c|c|}
\hline & $\begin{array}{l}\text { Above- } \\
\text { Average GPA }\end{array}$ & $\begin{array}{l}\text { Below- } \\
\text { Average GPA }\end{array}$ & Difference & P-value & $\begin{array}{l}\text { Attend } \\
\text { College }\end{array}$ & $\begin{array}{l}\text { Not Attend } \\
\text { College }\end{array}$ & Difference & P-value \\
\hline Female & $\begin{array}{l}3.69 \\
(5.47)\end{array}$ & $\begin{array}{l}3.48 \\
(6.15)\end{array}$ & 0.21 & 0.76 & $\begin{array}{l}3.65 \\
(5.80)\end{array}$ & $\begin{array}{l}3.11 \\
(5.61)\end{array}$ & 0.54 & 0.61 \\
\hline Male & $\begin{array}{l}2.88 \\
(4.70)\end{array}$ & $\begin{array}{l}2.00 \\
(3.63)\end{array}$ & 0.88 & 0.13 & $\begin{array}{l}2.60 \\
(4.40)\end{array}$ & $\begin{array}{l}1.40 \\
(2.65)\end{array}$ & 1.20 & 0.01 \\
\hline
\end{tabular}

Notes: Standard deviations are in parentheses. These results use survey weights. 
Table 3. The Effects of Homework Time on Achievement

\begin{tabular}{|c|c|c|c|c|}
\hline & \multicolumn{2}{|c|}{ GPA (OLS) } & \multicolumn{2}{|c|}{ College Attendance by Age 20 (Probit) } \\
\hline & $\begin{array}{c}\text { Female } \\
(\mathrm{N}=438)\end{array}$ & $\begin{array}{c}\text { Male } \\
(\mathrm{N}=367)\end{array}$ & $\begin{array}{c}\text { Female } \\
(\mathrm{N}=438)\end{array}$ & $\begin{array}{c}\text { Male } \\
(\mathrm{N}=367)\end{array}$ \\
\hline & (1) & $(2)$ & (3) & (4) \\
\hline \multicolumn{5}{|c|}{ Panel A. Total Homework } \\
\hline Homework & $\begin{array}{c}0.0669 \\
(0.0825)\end{array}$ & $\begin{array}{c}0.0602 \\
(0.143)\end{array}$ & $\begin{array}{l}-0.0018 \\
(0.002)\end{array}$ & $\begin{array}{c}0.0074 * * \\
(0.004)\end{array}$ \\
\hline $\mathrm{R}^{2}$ & 0.14 & 0.18 & & \\
\hline Pseudo $\mathrm{R}^{2}$ & & & 0.38 & 0.25 \\
\hline \multicolumn{5}{|c|}{ Panel B. Homework as a Primary Activity } \\
\hline Homework & $\begin{array}{c}0.0802 \\
(0.0874)\end{array}$ & $\begin{array}{l}0.0408 \\
(0.141)\end{array}$ & $\begin{array}{l}-0.0021 \\
(0.002)\end{array}$ & $\begin{array}{c}0.0073 * * \\
(0.004)\end{array}$ \\
\hline $\mathrm{R}^{2}$ & 0.14 & 0.18 & & \\
\hline Pseudo $\mathrm{R}^{2}$ & & & 0.38 & 0.25 \\
\hline \multicolumn{5}{|c|}{ Panel C. Homework as a Sole Activity } \\
\hline Homework & $\begin{array}{c}-0.0109 \\
(0.1129)\end{array}$ & $\begin{array}{c}0.3784 * * * \\
(0.1302)\end{array}$ & $\begin{array}{l}-0.0038 \\
(0.003)\end{array}$ & $\begin{array}{c}0.0082^{* *} \\
(0.004)\end{array}$ \\
\hline $\mathrm{R}^{2}$ & 0.14 & 0.19 & & \\
\hline Pseudo $\mathrm{R}^{2}$ & & & 0.39 & 0.24 \\
\hline \multicolumn{5}{|c|}{$\begin{array}{l}\text { Note: Survey weights are used. Average marginal effects are presented for the probit models. Standard errors are in parentheses and } \\
\text { are adjusted for clustering on state. All regressions include WJ-R reading and applied-problems scores, the number of household } \\
\text { children under age } 20 \text {, family income and its square, the fraction of the respondent's high school that was white, the fraction of the } \\
\text { respondent's high school that was free- or reduced-price-lunch eligible, and the respondent's high school's student-teacher ratio, and } \\
\text { indicators for WJ-R score missing, race, Census region, year prior to the student graduating from high school, living in a state that } \\
\text { requires college entrance exam, lives with single mother, lives in other family arrangement, mother college degree, mother college } \\
\text { degree missing, free/reduced-price lunch recipient, cohort, and a constant. Significance levels: }{ }^{* * *} \mathrm{p}<0.01 ;{ }^{* *} \mathrm{p}<0.05 \text {; }{ }^{*} \mathrm{p}<0.10 \text {. }\end{array}$} \\
\hline
\end{tabular}


Table 4. The Effects of Total Homework on Achievement with Controls for Endogeneity (LIML)

GPA

College Attendance by Age 20

\begin{tabular}{|c|c|c|c|c|}
\hline & $\begin{array}{l}\text { Female } \\
(\mathrm{N}=438)\end{array}$ & $\begin{array}{c}\text { Male } \\
(\mathrm{N}=367)\end{array}$ & $\begin{array}{l}\text { Female } \\
(\mathrm{N}=438)\end{array}$ & $\begin{array}{c}\text { Male } \\
(\mathrm{N}=367)\end{array}$ \\
\hline & (1) & (2) & (3) & (4) \\
\hline \multicolumn{5}{|l|}{ Panel A. Total Homework } \\
\hline Homework & $\begin{array}{c}0.4896 \\
(0.3589)\end{array}$ & $\begin{array}{l}-0.0311 \\
(0.4508)\end{array}$ & $\begin{array}{l}-0.0027 \\
(0.0039)\end{array}$ & $\begin{array}{c}0.0072 \\
(0.0099)\end{array}$ \\
\hline \multicolumn{5}{|l|}{ Exclusion restrictions } \\
\hline Friday diary & $\begin{array}{c}-5.3069 * * * \\
(1.0441)\end{array}$ & $\begin{array}{c}-2.7434 * * * \\
(0.7162)\end{array}$ & $\begin{array}{c}-5.6210 * * * \\
(0.9572)\end{array}$ & $\begin{array}{c}-2.7562 * * * \\
(0.6968)\end{array}$ \\
\hline Saturday diary & & $\begin{array}{c}-1.8821^{* *} \\
(0.8371)\end{array}$ & & $\begin{array}{c}-1.9452 * * \\
(0.8438)\end{array}$ \\
\hline Spring interview & $\begin{array}{c}-2.0383 * * * \\
(0.7645)\end{array}$ & & $\begin{array}{l}-1.7605^{* *} \\
(0.7740)\end{array}$ & \\
\hline Weekday precipitation & $\begin{array}{c}-0.0167 * * * \\
(0.0064)\end{array}$ & & $\begin{array}{l}-0.0115^{* *} \\
(0.0056)\end{array}$ & \\
\hline $\begin{array}{l}\text { Older than state minimum } \\
\text { driving age }\end{array}$ & & $\begin{array}{l}3.6511^{*} \\
(2.1427)\end{array}$ & & $\begin{array}{l}3.5489 * \\
(1.8730)\end{array}$ \\
\hline$\rho$, correlation coefficient & $\begin{array}{l}-0.29 \\
(0.20) \\
\end{array}$ & $\begin{array}{c}0.05 \\
(0.25) \\
\end{array}$ & $\begin{array}{c}0.06 \\
(0.25) \\
\end{array}$ & $\begin{array}{c}0.01 \\
(0.46) \\
\end{array}$ \\
\hline \multicolumn{5}{|c|}{ Panel B. Homework as a Primary Activity } \\
\hline Homework & $\begin{array}{c}0.6112 \\
(0.3731)\end{array}$ & $\begin{array}{l}-0.0564 \\
(0.4660)\end{array}$ & $\begin{array}{l}-0.0033 \\
(0.0041)\end{array}$ & $\begin{array}{c}0.0074 \\
(0.0103)\end{array}$ \\
\hline \multicolumn{5}{|l|}{ Exclusion restrictions } \\
\hline Friday diary & $\begin{array}{l}-4.7361^{* * *} \\
(1.0654)\end{array}$ & $\begin{array}{c}-2.6628 * * * \\
(0.6881)\end{array}$ & $\begin{array}{c}-5.1861^{* * *} \\
(0.9240)\end{array}$ & $\begin{array}{c}-2.6831^{* * * *} \\
(0.6664)\end{array}$ \\
\hline Saturday diary & & $\begin{array}{c}-1.7354 * * \\
(0.8631)\end{array}$ & & $\begin{array}{l}-1.7958 * * \\
(0.8572)\end{array}$ \\
\hline Spring interview & $\begin{array}{c}-2.1088 * * * \\
(0.6415)\end{array}$ & & $\begin{array}{c}-1.8392 * * * \\
(0.7346)\end{array}$ & \\
\hline Weekday precipitation & $\begin{array}{c}-0.0211^{* * *} \\
(0.0058)\end{array}$ & & $\begin{array}{c}-0.0115^{* *} \\
(0.0050)\end{array}$ & \\
\hline $\begin{array}{l}\text { Older than state minimum } \\
\text { driving age }\end{array}$ & & $\begin{array}{l}3.6148 * \\
(2.1098)\end{array}$ & & $\begin{array}{l}3.5157 * \\
(1.8603)\end{array}$ \\
\hline$\rho$, correlation coefficient & $\begin{array}{l}-0.35^{*} \\
(0.19)\end{array}$ & $\begin{array}{c}0.06 \\
(0.25)\end{array}$ & $\begin{array}{c}0.08 \\
(0.25)\end{array}$ & $\begin{array}{l}-0.00 \\
(0.47)\end{array}$ \\
\hline
\end{tabular}




\begin{tabular}{|c|c|c|c|c|}
\hline \multicolumn{5}{|c|}{ Panel C. Homework as a Sole Activity } \\
\hline Homework & $\begin{array}{c}1.5904 \\
(2.2049)\end{array}$ & $\begin{array}{c}0.8931 \\
(0.8957)\end{array}$ & $\begin{array}{l}-0.0050 \\
(0.0105)\end{array}$ & $\begin{array}{c}0.0073 \\
(0.0193)\end{array}$ \\
\hline \multicolumn{5}{|l|}{ Exclusion restrictions } \\
\hline Friday diary & $\begin{array}{l}-1.8747 \\
(1.8005)\end{array}$ & $\begin{array}{c}-1.6638 * * * \\
(0.3599)\end{array}$ & $\begin{array}{c}-2.6656^{* * * *} \\
(0.6299)\end{array}$ & $\begin{array}{c}-1.7202^{* * *} \\
(0.3531)\end{array}$ \\
\hline Saturday diary & & $\begin{array}{c}-1.4353 * * \\
(0.6741)\end{array}$ & & $\begin{array}{l}-1.4051^{*} \\
(0.7753)\end{array}$ \\
\hline Spring interview & $\begin{array}{l}-0.5304 \\
(0.5778)\end{array}$ & & $\begin{array}{c}0.0882 \\
(0.6414)\end{array}$ & \\
\hline Weekday precipitation & $\begin{array}{c}-0.0106^{* *} \\
(0.0048)\end{array}$ & & $\begin{array}{l}-0.0036 \\
(0.0061)\end{array}$ & \\
\hline $\begin{array}{l}\text { Older than state minimum } \\
\text { driving age }\end{array}$ & & $\begin{array}{c}0.1261 \\
(0.8572)\end{array}$ & & $\begin{array}{c}0.3418 \\
(0.5561)\end{array}$ \\
\hline$\rho$, correlation coefficient & $\begin{array}{l}-0.63 \\
(0.50)\end{array}$ & $\begin{array}{l}-0.18 \\
(0.30)\end{array}$ & $\begin{array}{c}0.06 \\
(0.51)\end{array}$ & $\begin{array}{c}0.02 \\
(0.56)\end{array}$ \\
\hline
\end{tabular}

Note: Survey weights are used. Average marginal effects are presented for the probit models. Robust standard errors are in parentheses and are adjusted for clustering on state. Regressions include all control variables listed in Table 3. Significance levels: ${ }^{* * *} \mathrm{p}<0.01 ;{ }^{* *} \mathrm{p}<0.05 ;{ }^{*} \mathrm{p}<0.10$ 


\section{Appendix}

\section{Appendix Table A1. Sample Selection}

\begin{tabular}{|c|c|}
\hline & $\begin{array}{c}\text { Number of } \\
\text { Observations }\end{array}$ \\
\hline Attend high school in CDS2 or CDS3 (27 dropouts prior to interview) & 1,648 \\
\hline Drop those who didn't complete both a weekday and weekend day diary & 1,429 \\
\hline $\begin{array}{l}\text { Drop those interviewed during winter break and in June when they do not } \\
\text { attend school on diary day }\end{array}$ & 1,287 \\
\hline Drop those missing child interview in 2007 & 1,273 \\
\hline Drop if missing race & 1270 \\
\hline Drop if family income is negative ( 1 case) & 1,266 \\
\hline $\begin{array}{l}\text { Drop if missing follow-up TA information on education (including high } \\
\text { school completion, college attendance by age } 20 \text { - but not GPA) }\end{array}$ & 1,073 \\
\hline Drop those with missing diary date & 1,027 \\
\hline Drop private high school students & 953 \\
\hline Drop if no 2003 main family interview & 949 \\
\hline Drop if missing school-level variables & 935 \\
\hline Drop if did not graduate from high school & 807 \\
\hline Drop if missing weather data & 805 \\
\hline Analysis Sample & 805 \\
\hline Females & 438 \\
\hline Males & 367 \\
\hline
\end{tabular}


Table A2. GPA Regressions (Exogenous Homework): Other Coefficient Estimates

\begin{tabular}{|c|c|c|c|c|c|c|}
\hline \multirow[b]{2}{*}{ Variables } & \multicolumn{2}{|c|}{ Total Homework } & \multicolumn{2}{|c|}{$\begin{array}{c}\text { Homework as a Primary } \\
\text { Activity }\end{array}$} & \multicolumn{2}{|c|}{$\begin{array}{c}\text { Homework as a Sole } \\
\text { Activity }\end{array}$} \\
\hline & $\begin{array}{c}\text { Female } \\
\text { (1) }\end{array}$ & $\begin{array}{c}\text { Male } \\
(2)\end{array}$ & $\begin{array}{c}\text { Female } \\
\text { (3) }\end{array}$ & $\begin{array}{c}\text { Male } \\
(4)\end{array}$ & $\begin{array}{c}\text { Female } \\
\text { (5) }\end{array}$ & $\begin{array}{c}\text { Male } \\
(6)\end{array}$ \\
\hline Homework time & $\begin{array}{l}0.0669 \\
(0.0825)\end{array}$ & $\begin{array}{l}0.0602 \\
(0.1434)\end{array}$ & $\begin{array}{l}0.0802 \\
(0.0874)\end{array}$ & $\begin{array}{l}0.0408 \\
(0.1409)\end{array}$ & $\begin{array}{l}-0.0109 \\
(0.1129)\end{array}$ & $\begin{array}{l}0.3784 * * * \\
(0.1302)\end{array}$ \\
\hline Black/Hispanic & $\begin{array}{l}-2.0657 \\
(1.9494)\end{array}$ & $\begin{array}{l}-2.0449 \\
(2.2488)\end{array}$ & $\begin{array}{l}-2.0598 \\
(1.9695)\end{array}$ & $\begin{array}{l}-2.0631 \\
(2.2300)\end{array}$ & $\begin{array}{l}-2.1372 \\
(1.9232)\end{array}$ & $\begin{array}{l}-2.5303 \\
(2.1830)\end{array}$ \\
\hline Reading score & $\begin{array}{l}0.0423 \\
(0.0499)\end{array}$ & $\begin{array}{l}0.0629 \\
(0.0797)\end{array}$ & $\begin{array}{l}0.0422 \\
(0.0497)\end{array}$ & $\begin{array}{l}0.0624 \\
(0.0794)\end{array}$ & $\begin{array}{l}0.0439 \\
(0.0500)\end{array}$ & $\begin{array}{l}0.0698 \\
(0.0846)\end{array}$ \\
\hline Applied-problems score & $\begin{array}{l}0.1496^{* *} \\
(0.0711)\end{array}$ & $\begin{array}{l}0.0671 \\
(0.0593)\end{array}$ & $\begin{array}{l}0.1487 * * \\
(0.0708)\end{array}$ & $\begin{array}{l}0.0684 \\
(0.0602)\end{array}$ & $\begin{array}{l}0.1492 * * \\
(0.0709)\end{array}$ & $\begin{array}{l}0.0470 \\
(0.0637)\end{array}$ \\
\hline State-mandated college exam & $\begin{array}{l}-0.3782 \\
(2.5053)\end{array}$ & $\begin{array}{l}3.4308 \\
(2.1190)\end{array}$ & $\begin{array}{l}-0.3653 \\
(2.5003)\end{array}$ & $\begin{array}{l}3.3716 \\
(2.1413)\end{array}$ & $\begin{array}{l}-0.4088 \\
(2.4893)\end{array}$ & $\begin{array}{l}3.3864^{*} \\
(1.9494)\end{array}$ \\
\hline Lives with single mother & $\begin{array}{l}-1.9062 \\
(1.4677)\end{array}$ & $\begin{array}{l}-5.8886 \\
(3.6919)\end{array}$ & $\begin{array}{l}-1.9192 \\
(1.4584)\end{array}$ & $\begin{array}{l}-5.8665 \\
(3.6888)\end{array}$ & $\begin{array}{l}-1.8336 \\
(1.4706)\end{array}$ & $\begin{array}{l}-5.6708 \\
(3.5251)\end{array}$ \\
\hline Lives in other family arrangement & $\begin{array}{l}-6.9347 \\
(4.1559)\end{array}$ & $\begin{array}{l}-6.8144 \\
(8.0607)\end{array}$ & $\begin{array}{l}-7.0907 * \\
(4.1627)\end{array}$ & $\begin{array}{l}-6.8617 \\
(7.9943)\end{array}$ & $\begin{array}{l}-7.1080 * \\
(4.0479)\end{array}$ & $\begin{array}{l}-7.0332 \\
(7.4534)\end{array}$ \\
\hline Number of household siblings & $\begin{array}{l}0.6556 \\
(0.5386)\end{array}$ & $\begin{array}{l}0.8091 \\
(0.7066)\end{array}$ & $\begin{array}{l}0.6648 \\
(0.5336)\end{array}$ & $\begin{array}{l}0.8136 \\
(0.7091)\end{array}$ & $\begin{array}{l}0.6473 \\
(0.5531)\end{array}$ & $\begin{array}{l}0.6365 \\
(0.6893)\end{array}$ \\
\hline Household income (in \$1,000s) & $\begin{array}{l}-0.0066 \\
(0.0153)\end{array}$ & $\begin{array}{l}-0.0023 \\
(0.0203)\end{array}$ & $\begin{array}{l}-0.0068 \\
(0.0152)\end{array}$ & $\begin{array}{l}-0.0022 \\
(0.0204)\end{array}$ & $\begin{array}{l}-0.0048 \\
(0.0160)\end{array}$ & $\begin{array}{l}-0.0032 \\
(0.0202)\end{array}$ \\
\hline Household income squared (in $\$ 1,000$ s) & $\begin{array}{l}0.0000 \\
(0.0000)\end{array}$ & $\begin{array}{l}-0.0000 \\
(0.0000)\end{array}$ & $\begin{array}{l}0.0000 \\
(0.0000)\end{array}$ & $\begin{array}{l}-0.0000 \\
(0.0000)\end{array}$ & $\begin{array}{l}0.0000 \\
(0.0000)\end{array}$ & $\begin{array}{l}-0.0000 \\
(0.0000)\end{array}$ \\
\hline Mother college & $\begin{array}{l}2.5718 \\
(1.7625)\end{array}$ & $\begin{array}{l}6.2888 * * * \\
(1.7171)\end{array}$ & $\begin{array}{l}2.5265 \\
(1.7715)\end{array}$ & $\begin{array}{l}6.3629 * * * \\
(1.7314)\end{array}$ & $\begin{array}{l}2.7756 \\
(1.6973)\end{array}$ & $\begin{array}{l}6.6847^{* * *} \\
(1.7830)\end{array}$ \\
\hline Fraction free/reduced-price lunch & $\begin{array}{l}3.8649 \\
(2.9835)\end{array}$ & $\begin{array}{l}9.1011^{* *} \\
(4.0977)\end{array}$ & $\begin{array}{l}3.8286 \\
(3.0118)\end{array}$ & $\begin{array}{l}9.0891 * * \\
(4.1203)\end{array}$ & $\begin{array}{l}3.9179 \\
(3.0339)\end{array}$ & $\begin{array}{l}9.2844 * * \\
(4.0335)\end{array}$ \\
\hline Student-teacher ratio & $\begin{array}{l}0.0551 \\
(0.2246)\end{array}$ & $\begin{array}{l}-0.2026 \\
(0.2025)\end{array}$ & $\begin{array}{l}0.0553 \\
(0.2237)\end{array}$ & $\begin{array}{l}-0.2007 \\
(0.2002)\end{array}$ & $\begin{array}{l}0.0445 \\
(0.2263)\end{array}$ & $\begin{array}{l}-0.1790 \\
(0.1891)\end{array}$ \\
\hline Fraction white & $\begin{array}{l}1.6401 \\
(2.3412)\end{array}$ & $\begin{array}{l}1.8833 \\
(4.0798)\end{array}$ & $\begin{array}{l}1.6731 \\
(2.3332)\end{array}$ & $\begin{array}{l}1.8140 \\
(4.0579)\end{array}$ & $\begin{array}{l}1.5961 \\
(2.3556)\end{array}$ & $\begin{array}{l}2.0536 \\
(4.2702)\end{array}$ \\
\hline Observations & 438 & 367 & 438 & 367 & 438 & 367 \\
\hline
\end{tabular}

Notes: Survey weights are used. Standard errors clustered on state are in parentheses. All regressions also include indicators for Census region, year effects, missing WJ-R score, missing mother's education, missing school, and a constant. Significance levels: ${ }^{* * *} \mathrm{p}<0.01,{ }^{* *} \mathrm{p}<0.05$, * $\mathrm{p}<0.1$. 
Table A3. College by Age 20 Probits (Exogenous Homework): Other Marginal Effects

\begin{tabular}{|c|c|c|c|c|c|c|}
\hline \multirow[b]{2}{*}{ Variables } & \multicolumn{2}{|c|}{ Total Homework } & \multicolumn{2}{|c|}{$\begin{array}{c}\text { Homework as a Primary } \\
\text { Activity }\end{array}$} & \multicolumn{2}{|c|}{$\begin{array}{c}\text { Homework as a Sole } \\
\text { Activity } \\
\end{array}$} \\
\hline & $\begin{array}{c}\text { Female } \\
(1)\end{array}$ & $\begin{array}{c}\text { Male } \\
(2)\end{array}$ & $\begin{array}{c}\text { Female } \\
\text { (3) }\end{array}$ & $\begin{array}{c}\text { Male } \\
(4)\end{array}$ & $\begin{array}{c}\text { Female } \\
\text { (5) }\end{array}$ & $\begin{array}{c}\text { Male } \\
(6)\end{array}$ \\
\hline \multirow[t]{2}{*}{ Homework time } & -0.0018 & $0.0074 * *$ & -0.0021 & $0.0073 * *$ & -0.0038 & $0.0082 * *$ \\
\hline & $(0.0019)$ & $(0.0036)$ & $(0.0020)$ & $(0.0036)$ & $(0.0029)$ & $(0.0036)$ \\
\hline \multirow[t]{2}{*}{ Black/Hispanic } & $0.0773 * *$ & 0.0062 & $0.0772 * *$ & 0.0066 & $0.0777 * *$ & 0.0000 \\
\hline & $(0.0388)$ & $(0.0497)$ & $(0.0388)$ & $(0.0496)$ & $(0.0377)$ & $(0.0490)$ \\
\hline \multirow[t]{2}{*}{ Reading score } & $0.0020^{*}$ & 0.0013 & $0.0020 * *$ & 0.0013 & $0.0021^{*}$ & 0.0013 \\
\hline & $(0.0010)$ & $(0.0016)$ & $(0.0010)$ & $(0.0016)$ & $(0.0011)$ & $(0.0016)$ \\
\hline \multirow[t]{2}{*}{ Applied-problems score } & $0.0042 * * *$ & $0.0037^{*}$ & $0.0042^{* * *}$ & $0.0037^{*}$ & $0.0044 * * *$ & $0.0034^{*}$ \\
\hline & $(0.0010)$ & $(0.0019)$ & $(0.0010)$ & $(0.0019)$ & $(0.0010)$ & $(0.0020)$ \\
\hline \multirow[t]{2}{*}{ State-mandated college exam } & $0.0749 *$ & $0.1563 * * *$ & $0.0749 *$ & $0.1562 * * *$ & $0.0872 * *$ & $0.1485^{* * *}$ \\
\hline & $(0.0390)$ & $(0.0515)$ & $(0.0389)$ & $(0.0513)$ & $(0.0343)$ & $(0.0504)$ \\
\hline \multirow[t]{2}{*}{ Lives with single mother } & -0.0398 & -0.0107 & -0.0398 & -0.0116 & -0.0367 & -0.0138 \\
\hline & $(0.0310)$ & $(0.0446)$ & $(0.0313)$ & $(0.0443)$ & $(0.0306)$ & $(0.0439)$ \\
\hline \multirow[t]{2}{*}{ Lives in other family arrangement } & -0.0395 & 0.0648 & -0.0384 & 0.0640 & -0.0457 & 0.0497 \\
\hline & $(0.0618)$ & $(0.0874)$ & $(0.0620)$ & $(0.0870)$ & $(0.0595)$ & $(0.0901)$ \\
\hline \multirow[t]{2}{*}{ Number of household siblings } & $0.0183^{*}$ & -0.0125 & $0.0177 *$ & -0.0129 & $0.0195 * *$ & -0.0144 \\
\hline & $(0.0096)$ & $(0.0198)$ & $(0.0100)$ & $(0.0196)$ & $(0.0089)$ & $(0.0201)$ \\
\hline \multirow[t]{2}{*}{ Household income (in $\$ 1,000$ s) } & $0.0019 * * *$ & -0.0002 & $0.0019 * * *$ & -0.0002 & $0.0019 * * *$ & -0.0002 \\
\hline & $(0.0006)$ & $(0.0007)$ & $(0.0006)$ & $(0.0007)$ & $(0.0006)$ & $(0.0006)$ \\
\hline \multirow[t]{2}{*}{ Household income squared (in $\$ 1,000$ s) } & $-0.0000 * * *$ & 0.0000 & $-0.0000 * * *$ & 0.0000 & $-0.0000 *$ & 0.0000 \\
\hline & $(0.0000)$ & $(0.0000)$ & $(0.0000)$ & $(0.0000)$ & $(0.0000)$ & $(0.0000)$ \\
\hline \multirow[t]{2}{*}{ Mother college } & $0.1015^{* *}$ & 0.0849 & $0.1019 * *$ & 0.0856 & $0.1045^{* *}$ & $0.0999 *$ \\
\hline & $(0.0473)$ & $(0.0625)$ & $(0.0472)$ & $(0.0625)$ & $(0.0474)$ & $(0.0607)$ \\
\hline \multirow[t]{2}{*}{ Fraction free/reduced-price lunch } & 0.0570 & $-0.1940 * *$ & 0.0590 & $-0.1947 * *$ & 0.0542 & $-0.1907 * *$ \\
\hline & $(0.0449)$ & $(0.0863)$ & $(0.0461)$ & $(0.0866)$ & $(0.0481)$ & $(0.0869)$ \\
\hline \multirow[t]{2}{*}{ Student-teacher ratio } & -0.0018 & -0.0025 & -0.0018 & -0.0024 & -0.0021 & -0.0014 \\
\hline & $(0.0023)$ & $(0.0042)$ & $(0.0023)$ & $(0.0043)$ & $(0.0024)$ & $(0.0044)$ \\
\hline \multirow[t]{2}{*}{ Fraction white } & -0.0229 & -0.0038 & -0.0237 & -0.0050 & -0.0225 & -0.0096 \\
\hline & $(0.0425)$ & $(0.0835)$ & $(0.0423)$ & $(0.0835)$ & $(0.0421)$ & $(0.0819)$ \\
\hline Observations & 438 & 367 & 438 & 367 & 438 & 367 \\
\hline
\end{tabular}

Notes: Survey weights are used. Standard errors clustered on state are in parentheses. All regressions also include indicators for Census region, year effects, missing WJ-R score, missing mother's education, missing school, and a constant. Significance levels: ${ }^{* * *} \mathrm{p}<0.01,{ }^{* *} \mathrm{p}<0.05$, ${ }^{*} \mathrm{p}<0.1$. 
Table A4. GPA Regressions (Endogenous Homework): Other Coefficient Estimates

\begin{tabular}{|c|c|c|c|c|c|c|}
\hline \multirow[b]{2}{*}{ Variables } & \multicolumn{2}{|c|}{ Total Homework } & \multicolumn{2}{|c|}{$\begin{array}{c}\text { Homework as a Primary } \\
\text { Activity }\end{array}$} & \multicolumn{2}{|c|}{$\begin{array}{c}\text { Homework as a Sole } \\
\text { Activity }\end{array}$} \\
\hline & $\begin{array}{l}\text { Female } \\
\text { (1) }\end{array}$ & $\begin{array}{l}\text { Male } \\
(2)\end{array}$ & $\begin{array}{l}\text { Female } \\
\text { (3) }\end{array}$ & $\begin{array}{l}\text { Male } \\
\text { (4) }\end{array}$ & $\begin{array}{l}\text { Female } \\
\text { (5) }\end{array}$ & $\begin{array}{l}\text { Male } \\
(6)\end{array}$ \\
\hline Homework time & $\begin{array}{l}0.4896 \\
(0.3589)\end{array}$ & $\begin{array}{l}0.6790 \\
(0.5418)\end{array}$ & $\begin{array}{l}0.6112 \\
(0.3731)\end{array}$ & $\begin{array}{l}0.7130 \\
(0.5773)\end{array}$ & $\begin{array}{l}1.5904 \\
(2.2049)\end{array}$ & $\begin{array}{l}0.9456 \\
(0.6785)\end{array}$ \\
\hline Black/Hispanic & $\begin{array}{l}-1.7255 \\
(1.9568)\end{array}$ & $\begin{array}{l}-1.2404 \\
(2.9678)\end{array}$ & $\begin{array}{l}-1.6647 \\
(2.1067)\end{array}$ & $\begin{array}{l}-1.0719 \\
(3.0588)\end{array}$ & $\begin{array}{l}0.4525 \\
(4.2093)\end{array}$ & $\begin{array}{l}-3.1407 \\
(2.2513)\end{array}$ \\
\hline Reading score & $\begin{array}{l}0.0343 \\
(0.0495)\end{array}$ & $\begin{array}{l}0.0670 \\
(0.0857)\end{array}$ & $\begin{array}{l}0.0328 \\
(0.0490)\end{array}$ & $\begin{array}{l}0.0614 \\
(0.0861)\end{array}$ & $\begin{array}{l}0.0086 \\
(0.0610)\end{array}$ & $\begin{array}{l}0.0808 \\
(0.0896)\end{array}$ \\
\hline Applied-problems score & $\begin{array}{l}0.1529 * * \\
(0.0711)\end{array}$ & $\begin{array}{l}0.0407 \\
(0.0759)\end{array}$ & $\begin{array}{l}0.1459 * * \\
(0.0709)\end{array}$ & $\begin{array}{l}0.0473 \\
(0.0781)\end{array}$ & $\begin{array}{l}0.1353^{*} \\
(0.0772)\end{array}$ & $\begin{array}{l}0.0131 \\
(0.0765)\end{array}$ \\
\hline State-mandated college exam & $\begin{array}{l}-0.1737 \\
(2.5818)\end{array}$ & $\begin{array}{l}5.7895^{*} \\
(3.4996)\end{array}$ & $\begin{array}{l}-0.0652 \\
(2.5424)\end{array}$ & $\begin{array}{l}6.1835 \\
(3.7667)\end{array}$ & $\begin{array}{l}-0.6660 \\
(2.6427)\end{array}$ & $\begin{array}{l}3.6642 * \\
(1.9325)\end{array}$ \\
\hline Lives with single mother & $\begin{array}{l}-2.3055 \\
(1.4843)\end{array}$ & $\begin{array}{l}-6.6415^{*} \\
(3.9930)\end{array}$ & $\begin{array}{l}-2.4239 * \\
(1.4679)\end{array}$ & $\begin{array}{l}-6.7106^{*} \\
(3.9595)\end{array}$ & $\begin{array}{l}-3.2002 \\
(2.9293)\end{array}$ & $\begin{array}{l}-5.4542 * \\
(3.0884)\end{array}$ \\
\hline Lives in other family arrangement & $\begin{array}{l}-5.9792 \\
(5.0085)\end{array}$ & $\begin{array}{l}-5.5032 \\
(8.9052)\end{array}$ & $\begin{array}{l}-7.1212 \\
(4.9966)\end{array}$ & $\begin{array}{l}-5.5368 \\
(9.0620)\end{array}$ & $\begin{array}{l}-3.8896 \\
(7.7190)\end{array}$ & $\begin{array}{l}-7.1699 \\
(6.8725)\end{array}$ \\
\hline Number of household siblings & $\begin{array}{l}0.7163 \\
(0.4807)\end{array}$ & $\begin{array}{l}0.5764 \\
(0.6630)\end{array}$ & $\begin{array}{l}0.7897^{*} \\
(0.4769)\end{array}$ & $\begin{array}{l}0.5151 \\
(0.6624)\end{array}$ & $\begin{array}{l}0.4524 \\
(0.8308)\end{array}$ & $\begin{array}{l}0.3437 \\
(0.7195)\end{array}$ \\
\hline Household income (in $\$ 1,000$ s) & $\begin{array}{l}-0.0166 \\
(0.0157)\end{array}$ & $\begin{array}{l}-0.0034 \\
(0.0185)\end{array}$ & $\begin{array}{l}-0.0187 \\
(0.0153)\end{array}$ & $\begin{array}{l}-0.0021 \\
(0.0187)\end{array}$ & $\begin{array}{l}-0.0352 \\
(0.0450)\end{array}$ & $\begin{array}{l}-0.0046 \\
(0.0201)\end{array}$ \\
\hline Household income squared (in $\$ 1,000$ s) & $\begin{array}{l}0.0000 \\
(0.0000)\end{array}$ & $\begin{array}{l}-0.0000 \\
(0.0000)\end{array}$ & $\begin{array}{l}0.0000 \\
(0.0000)\end{array}$ & $\begin{array}{l}-0.0000 \\
(0.0000)\end{array}$ & $\begin{array}{l}0.0000 \\
(0.0000)\end{array}$ & $\begin{array}{l}-0.0000 \\
(0.0000)\end{array}$ \\
\hline Mother college & $\begin{array}{l}1.3470 \\
(2.4861)\end{array}$ & $\begin{array}{l}4.5759 * * \\
(2.2557)\end{array}$ & $\begin{array}{l}0.9420 \\
(2.6060)\end{array}$ & $\begin{array}{l}4.8335 * * \\
(2.1971)\end{array}$ & $\begin{array}{l}1.3317 \\
(3.9578)\end{array}$ & $\begin{array}{l}7.0282^{* * *} \\
(1.8453)\end{array}$ \\
\hline Fraction free/reduced-price lunch & $\begin{array}{l}3.5970 \\
(2.7675)\end{array}$ & $\begin{array}{l}8.8772 * * \\
(3.7527)\end{array}$ & $\begin{array}{l}3.3078 \\
(2.9347)\end{array}$ & $\begin{array}{l}8.5307 * * \\
(3.7748)\end{array}$ & $\begin{array}{l}2.3592 \\
(4.3897)\end{array}$ & $\begin{array}{l}9.5265 * * \\
(3.9044)\end{array}$ \\
\hline Student-teacher ratio & $\begin{array}{l}0.1246 \\
(0.2472)\end{array}$ & $\begin{array}{l}-0.2353 \\
(0.2250)\end{array}$ & $\begin{array}{l}0.1293 \\
(0.2430)\end{array}$ & $\begin{array}{l}-0.2203 \\
(0.2279)\end{array}$ & $\begin{array}{l}-0.0215 \\
(0.2006)\end{array}$ & $\begin{array}{l}-0.1482 \\
(0.1833)\end{array}$ \\
\hline Fraction white & $\begin{array}{l}1.8178 \\
(2.1450)\end{array}$ & $\begin{array}{l}3.8757 \\
(5.8577)\end{array}$ & $\begin{array}{l}2.0778 \\
(2.1868)\end{array}$ & $\begin{array}{l}3.8696 \\
(5.9631)\end{array}$ & $\begin{array}{l}3.9233 \\
(3.9213)\end{array}$ & $\begin{array}{l}2.5999 \\
(4.5551)\end{array}$ \\
\hline Observations & 438 & 367 & 438 & 367 & 438 & 367 \\
\hline
\end{tabular}

Notes: Survey weights are used. Standard errors clustered on state are in parentheses. All regressions also include indicators for Census region, year effects, missing WJ-R score, missing mother's education, missing school, and a constant. Significance levels: ${ }^{* * *} \mathrm{p}<0.01$, ** $\mathrm{p}<0.05,{ }^{*} \mathrm{p}<0.1$. 
Table A5. College by Age 20 Regressions (Endogenous Homework): Other Marginal Effects

\begin{tabular}{|c|c|c|c|c|c|c|}
\hline \multirow[b]{2}{*}{ Variables } & \multicolumn{2}{|c|}{ Total Homework } & \multicolumn{2}{|c|}{$\begin{array}{c}\text { Homework as a Primary } \\
\text { Activity }\end{array}$} & \multicolumn{2}{|c|}{$\begin{array}{l}\text { Homework as a Sole } \\
\text { Activity }\end{array}$} \\
\hline & $\begin{array}{l}\text { Female } \\
\text { (1) }\end{array}$ & $\begin{array}{l}\text { Male } \\
\text { (2) }\end{array}$ & $\begin{array}{l}\text { Female } \\
\text { (3) }\end{array}$ & $\begin{array}{l}\text { Male } \\
\text { (4) }\end{array}$ & $\begin{array}{l}\text { Female } \\
\text { (5) }\end{array}$ & $\begin{array}{l}\text { Male } \\
(6)\end{array}$ \\
\hline Homework time & $\begin{array}{l}-0.0027 \\
(0.0039)\end{array}$ & $\begin{array}{l}0.0055 \\
(0.0164)\end{array}$ & $\begin{array}{l}-0.0033 \\
(0.0041)\end{array}$ & $\begin{array}{l}0.0058 \\
(0.0180)\end{array}$ & $\begin{array}{l}-0.0050 \\
(0.0105)\end{array}$ & $\begin{array}{l}0.0073 \\
(0.0201)\end{array}$ \\
\hline Black/Hispanic & $\begin{array}{l}0.0763^{*} \\
(0.0400)\end{array}$ & $\begin{array}{l}0.0026 \\
(0.0469)\end{array}$ & $\begin{array}{l}0.0759 * \\
(0.0397)\end{array}$ & $\begin{array}{l}0.0036 \\
(0.0491)\end{array}$ & $\begin{array}{l}0.0757^{*} \\
(0.0438)\end{array}$ & $\begin{array}{l}0.0007 \\
(0.0574)\end{array}$ \\
\hline Reading score & $\begin{array}{l}0.0020 * \\
(0.0010)\end{array}$ & $\begin{array}{l}0.0013 \\
(0.0015)\end{array}$ & $\begin{array}{l}0.0020 * * \\
(0.0010)\end{array}$ & $\begin{array}{l}0.0013 \\
(0.0016)\end{array}$ & $\begin{array}{l}0.0021 * \\
(0.0012)\end{array}$ & $\begin{array}{l}0.0013 \\
(0.0016)\end{array}$ \\
\hline Applied-problems score & $\begin{array}{l}0.0042 * * * \\
(0.0010)\end{array}$ & $\begin{array}{l}0.0038 * * \\
(0.0017)\end{array}$ & $\begin{array}{l}0.0042^{* * * *} \\
(0.0010)\end{array}$ & $\begin{array}{l}0.0038 * * \\
(0.0018)\end{array}$ & $\begin{array}{l}0.0044^{* * * *} \\
(0.0010)\end{array}$ & $\begin{array}{l}0.0035^{*} \\
(0.0018)\end{array}$ \\
\hline State-mandated college exam & $\begin{array}{l}0.0746 * \\
(0.0387)\end{array}$ & $\begin{array}{l}0.1463 \\
(0.0931)\end{array}$ & $\begin{array}{l}0.0742 * \\
(0.0385)\end{array}$ & $\begin{array}{l}0.1479 \\
(0.1057)\end{array}$ & $\begin{array}{l}0.0875^{* *} \\
(0.0346)\end{array}$ & $\begin{array}{l}0.1476 * * * \\
(0.0537)\end{array}$ \\
\hline Lives with single mother & $\begin{array}{l}-0.0392 \\
(0.0304)\end{array}$ & $\begin{array}{l}-0.0081 \\
(0.0452)\end{array}$ & $\begin{array}{l}-0.0390 \\
(0.0309)\end{array}$ & $\begin{array}{l}-0.0096 \\
(0.0456)\end{array}$ & $\begin{array}{l}-0.0359 \\
(0.0277)\end{array}$ & $\begin{array}{l}-0.0141 \\
(0.0475)\end{array}$ \\
\hline Lives in other family arrangement & $\begin{array}{l}-0.0427 \\
(0.0629)\end{array}$ & $\begin{array}{l}0.0609 \\
(0.1045)\end{array}$ & $\begin{array}{l}-0.0397 \\
(0.0621)\end{array}$ & $\begin{array}{l}0.0612 \\
(0.1044)\end{array}$ & $\begin{array}{l}-0.0485 \\
(0.0638)\end{array}$ & $\begin{array}{l}0.0500 \\
(0.0872)\end{array}$ \\
\hline Number of household siblings & $\begin{array}{l}0.0184 * \\
(0.0098)\end{array}$ & $\begin{array}{l}-0.0115 \\
(0.0191)\end{array}$ & $\begin{array}{l}0.0177^{*} \\
(0.0102)\end{array}$ & $\begin{array}{l}-0.0121 \\
(0.0195)\end{array}$ & $\begin{array}{l}0.0198 * * \\
(0.0092)\end{array}$ & $\begin{array}{l}-0.0140 \\
(0.0187)\end{array}$ \\
\hline Household income (in \$1000s) & $\begin{array}{l}0.0019 * * * \\
(0.0006)\end{array}$ & $\begin{array}{l}-0.0002 \\
(0.0007)\end{array}$ & $\begin{array}{l}0.0019 * * * \\
(0.0006)\end{array}$ & $\begin{array}{l}-0.0002 \\
(0.0007)\end{array}$ & $\begin{array}{l}0.0019 * * * \\
(0.0006)\end{array}$ & $\begin{array}{l}-0.0002 \\
(0.0006)\end{array}$ \\
\hline Household income squared (in \$1000s) & $\begin{array}{l}-0.0000^{* * *} \\
(0.0000)\end{array}$ & $\begin{array}{l}0.0000 \\
(0.0000)\end{array}$ & $\begin{array}{l}-0.0000^{* * *} \\
(0.0000)\end{array}$ & $\begin{array}{l}0.0000 \\
(0.0000)\end{array}$ & $\begin{array}{l}-0.0000^{* *} \\
(0.0000)\end{array}$ & $\begin{array}{l}0.0000 \\
(0.0000)\end{array}$ \\
\hline Mother college & $\begin{array}{l}0.1052 * * \\
(0.0488)\end{array}$ & $\begin{array}{l}0.0904 * \\
(0.0525)\end{array}$ & $\begin{array}{l}0.1067 * * \\
(0.0493)\end{array}$ & $\begin{array}{l}0.0891^{*} \\
(0.0520)\end{array}$ & $\begin{array}{l}0.1066^{* *} \\
(0.0480)\end{array}$ & $\begin{array}{l}0.0996 \\
(0.0653)\end{array}$ \\
\hline Fraction free/reduced-price lunch & $\begin{array}{l}0.0574 \\
(0.0452)\end{array}$ & $\begin{array}{l}-0.1921^{* *} \\
(0.0852)\end{array}$ & $\begin{array}{l}0.0599 \\
(0.0470)\end{array}$ & $\begin{array}{l}-0.1926 * * \\
(0.0859)\end{array}$ & $\begin{array}{l}0.0553 \\
(0.0537)\end{array}$ & $\begin{array}{l}-0.1911^{* *} \\
(0.0882)\end{array}$ \\
\hline Student-teacher ratio & $\begin{array}{l}-0.0019 \\
(0.0023)\end{array}$ & $\begin{array}{l}-0.0024 \\
(0.0044)\end{array}$ & $\begin{array}{l}-0.0019 \\
(0.0023)\end{array}$ & $\begin{array}{l}-0.0023 \\
(0.0043)\end{array}$ & $\begin{array}{l}-0.0020 \\
(0.0026)\end{array}$ & $\begin{array}{l}-0.0014 \\
(0.0043)\end{array}$ \\
\hline Fraction white & $\begin{array}{l}-0.0232 \\
(0.0428)\end{array}$ & $\begin{array}{l}-0.0115 \\
(0.0785)\end{array}$ & $\begin{array}{l}-0.0245 \\
(0.0432)\end{array}$ & $\begin{array}{l}-0.0107 \\
(0.0787)\end{array}$ & $\begin{array}{l}-0.0242 \\
(0.0485)\end{array}$ & $\begin{array}{l}-0.0108 \\
(0.0700)\end{array}$ \\
\hline Observations & 438 & 367 & 438 & 367 & 438 & 367 \\
\hline
\end{tabular}

Notes: Survey weights are used. Standard errors clustered on state are in parentheses. All regressions also include indicators for Census region, year effects, missing WJ-R score, missing school, and a constant. Significance levels: *** $\mathrm{p}<0.01,{ }^{* *} \mathrm{p}<0.05,{ }^{*} \mathrm{p}<0.1$. 
Table A6. First-stage Homework Equations for GPA Specifications (Endogenous Homework)

\begin{tabular}{|c|c|c|c|c|c|c|}
\hline \multirow[b]{2}{*}{ Variables } & \multicolumn{2}{|c|}{ Total Homework } & \multicolumn{2}{|c|}{$\begin{array}{c}\text { Homework as a Primary } \\
\text { Activity }\end{array}$} & \multicolumn{2}{|c|}{$\begin{array}{l}\text { Homework as a Sole } \\
\text { Activity }\end{array}$} \\
\hline & $\begin{array}{l}\text { Female } \\
\text { (1) }\end{array}$ & $\begin{array}{l}\text { Male } \\
\text { (2) }\end{array}$ & $\begin{array}{l}\text { Female } \\
\text { (3) }\end{array}$ & $\begin{array}{l}\text { Male } \\
(4)\end{array}$ & $\begin{array}{l}\text { Female } \\
\text { (5) }\end{array}$ & $\begin{array}{l}\text { Male } \\
(6)\end{array}$ \\
\hline Friday diary & $\begin{array}{l}-5.3069 * * * \\
(1.0441)\end{array}$ & $\begin{array}{l}-2.7434 * * * \\
(0.7162)\end{array}$ & $\begin{array}{l}-4.7361 * * * \\
(1.0654)\end{array}$ & $\begin{array}{l}-2.6628 * * * \\
(0.6881)\end{array}$ & $\begin{array}{l}-1.8747 \\
(1.8005)\end{array}$ & $\begin{array}{l}-1.6638 * * * \\
(0.3599)\end{array}$ \\
\hline Saturday diary & & $\begin{array}{l}-1.8821^{* *} \\
(0.8371)\end{array}$ & & $\begin{array}{l}-1.7354^{* *} \\
(0.8631)\end{array}$ & & $\begin{array}{l}-1.4353^{* *} \\
(0.6741)\end{array}$ \\
\hline Spring interview & $\begin{array}{l}-2.0383^{* * *} \\
(0.7645)\end{array}$ & & $\begin{array}{l}-2.1088 * * * \\
(0.6415)\end{array}$ & & $\begin{array}{l}-0.5304 \\
(0.5778)\end{array}$ & \\
\hline Weekday precipitation & $\begin{array}{l}-0.0167 * * * \\
(0.0064)\end{array}$ & & $\begin{array}{l}-0.0211 * * * \\
(0.0058)\end{array}$ & & $\begin{array}{l}-0.0106 * * \\
(0.0048)\end{array}$ & \\
\hline $\begin{array}{l}\text { Older than state minimum } \\
\text { driving age }\end{array}$ & & $\begin{array}{l}3.6511^{*} \\
(2.1427)\end{array}$ & & $\begin{array}{l}3.6148^{*} \\
(2.1098)\end{array}$ & & $\begin{array}{l}0.1261 \\
(0.8572)\end{array}$ \\
\hline Black/Hispanic & $\begin{array}{l}-0.5884 \\
(0.9808)\end{array}$ & $\begin{array}{l}-0.7615 \\
(2.0016)\end{array}$ & $\begin{array}{l}-0.5046 \\
(1.0172)\end{array}$ & $\begin{array}{l}-0.9661 \\
(1.9847)\end{array}$ & $\begin{array}{l}-1.5347 \\
(1.0824)\end{array}$ & $\begin{array}{l}1.4600^{* *} \\
(0.5878)\end{array}$ \\
\hline Reading score & $\begin{array}{l}0.0081 \\
(0.0320)\end{array}$ & $\begin{array}{l}0.0072 \\
(0.0254)\end{array}$ & $\begin{array}{l}0.0074 \\
(0.0280)\end{array}$ & $\begin{array}{l}0.0145 \\
(0.0260)\end{array}$ & $\begin{array}{l}0.0182 \\
(0.0153)\end{array}$ & $\begin{array}{l}-0.0095 \\
(0.0217)\end{array}$ \\
\hline Applied-problems score & $\begin{array}{l}-0.0125 \\
(0.0373)\end{array}$ & $\begin{array}{l}0.0355 \\
(0.0461)\end{array}$ & $\begin{array}{l}0.0009 \\
(0.0369)\end{array}$ & $\begin{array}{l}0.0246 \\
(0.0493)\end{array}$ & $\begin{array}{l}0.0077 \\
(0.0219)\end{array}$ & $\begin{array}{l}0.0548 * * * \\
(0.0211)\end{array}$ \\
\hline $\begin{array}{l}\text { State-mandated college } \\
\text { exam }\end{array}$ & $\begin{array}{l}0.0550 \\
(0.7693)\end{array}$ & $\begin{array}{l}-3.3822 \\
(2.2678)\end{array}$ & $\begin{array}{l}-0.0423 \\
(0.6636)\end{array}$ & $\begin{array}{l}-3.7805 \\
(2.3275)\end{array}$ & $\begin{array}{l}0.3726 \\
(0.8025)\end{array}$ & $\begin{array}{l}-0.1853 \\
(0.8918)\end{array}$ \\
\hline Lives with single mother & $\begin{array}{l}0.6865 \\
(0.9745)\end{array}$ & $\begin{array}{l}1.2262 \\
(1.0633)\end{array}$ & $\begin{array}{l}0.7995 \\
(0.9297)\end{array}$ & $\begin{array}{l}1.2616 \\
(0.9284)\end{array}$ & $\begin{array}{l}0.8004 \\
(0.8491)\end{array}$ & $\begin{array}{l}-0.3770 \\
(1.0073)\end{array}$ \\
\hline $\begin{array}{l}\text { Lives in other family } \\
\text { arrangement }\end{array}$ & $\begin{array}{l}-3.1231 \\
(3.3967)\end{array}$ & $\begin{array}{l}-1.4860 \\
(2.9091)\end{array}$ & $\begin{array}{l}-0.8915 \\
(3.0864)\end{array}$ & $\begin{array}{l}-1.3767 \\
(3.0335)\end{array}$ & $\begin{array}{l}-2.5282 \\
(2.3815)\end{array}$ & $\begin{array}{l}0.6901 \\
(1.0909)\end{array}$ \\
\hline $\begin{array}{l}\text { Number of household } \\
\text { siblings }\end{array}$ & $\begin{array}{l}-0.2418 \\
(0.4675)\end{array}$ & $\begin{array}{l}0.2821 \\
(0.2951)\end{array}$ & $\begin{array}{l}-0.3467 \\
(0.4941)\end{array}$ & $\begin{array}{l}0.3545 \\
(0.2822)\end{array}$ & $\begin{array}{l}0.0701 \\
(0.2570)\end{array}$ & $\begin{array}{l}0.4485 * * * \\
(0.1736)\end{array}$ \\
\hline $\begin{array}{l}\text { Household income (in } \\
\$ 1,000 \text { s) }\end{array}$ & $\begin{array}{l}0.0232 * \\
(0.0128)\end{array}$ & $\begin{array}{l}0.0025 \\
(0.0089)\end{array}$ & $\begin{array}{l}0.0221^{*} \\
(0.0123)\end{array}$ & $\begin{array}{l}0.0006 \\
(0.0085)\end{array}$ & $\begin{array}{l}0.0190 * * * \\
(0.0073)\end{array}$ & $\begin{array}{l}0.0031 \\
(0.0075)\end{array}$ \\
\hline $\begin{array}{l}\text { Household income squared } \\
\text { (in } \$ 1,000 \text { s) }\end{array}$ & $\begin{array}{l}-0.0000^{* *} \\
(0.0000)\end{array}$ & $\begin{array}{l}-0.0000 \\
(0.0000)\end{array}$ & $\begin{array}{l}-0.0000 * * \\
(0.0000)\end{array}$ & $\begin{array}{l}0.0000 \\
(0.0000)\end{array}$ & $\begin{array}{l}-0.0000^{* * *} \\
(0.0000)\end{array}$ & $\begin{array}{l}-0.0000 \\
(0.0000)\end{array}$ \\
\hline Mother college & $\begin{array}{l}3.1578 * * * \\
(1.1893)\end{array}$ & $\begin{array}{l}2.4238^{*} \\
(1.4304)\end{array}$ & $\begin{array}{l}3.2403 * * * \\
(1.1288)\end{array}$ & $\begin{array}{l}1.9450 \\
(1.4540)\end{array}$ & $\begin{array}{l}0.9753 \\
(1.2248)\end{array}$ & $\begin{array}{l}-0.8542 \\
(0.6099)\end{array}$ \\
\hline $\begin{array}{l}\text { Fraction free/reduced-price } \\
\text { lunch }\end{array}$ & $\begin{array}{l}0.3825 \\
(2.0956)\end{array}$ & $\begin{array}{l}0.1570 \\
(1.7488)\end{array}$ & $\begin{array}{l}0.8976 \\
(1.8961)\end{array}$ & $\begin{array}{l}0.6380 \\
(1.8050)\end{array}$ & $\begin{array}{l}1.0129 \\
(1.8436)\end{array}$ & $\begin{array}{l}-0.5725 \\
(1.2187)\end{array}$ \\
\hline Student-teacher ratio & $\begin{array}{l}-0.1129 \\
(0.0815)\end{array}$ & $\begin{array}{l}0.0432 \\
(0.1259)\end{array}$ & $\begin{array}{l}-0.0877 \\
(0.0729)\end{array}$ & $\begin{array}{l}0.0200 \\
(0.1173)\end{array}$ & $\begin{array}{l}0.0618 \\
(0.0929)\end{array}$ & $\begin{array}{l}-0.0611 \\
(0.0529)\end{array}$ \\
\hline Fraction white & $\begin{array}{l}-0.3806 \\
(1.2385)\end{array}$ & $\begin{array}{l}-2.8279 \\
(2.5652)\end{array}$ & $\begin{array}{l}-0.6808 \\
(1.2556)\end{array}$ & $\begin{array}{l}-2.6858 \\
(2.6618)\end{array}$ & $\begin{array}{l}-1.4120 \\
(1.1355)\end{array}$ & $\begin{array}{l}-0.6821 \\
(0.9045)\end{array}$ \\
\hline Observations & 438 & 367 & 438 & 367 & 438 & 367 \\
\hline
\end{tabular}

Notes: Survey weights are used. Standard errors clustered on state are in parentheses. All regressions also include indicators for Census region, year effects, missing WJ-R score indicator, missing school indicator, and a constant. Significance levels: ${ }^{* * *} \mathrm{p}<0.01,{ }^{* *} \mathrm{p}<0.05, * \mathrm{p}<0.1$. 
Table A7. First-stage Homework Equations for College by Age 20 Probit Specifications (Endogenous Homework)

\begin{tabular}{|c|c|c|c|c|c|c|}
\hline \multirow[b]{2}{*}{ Variables } & \multicolumn{2}{|c|}{ Total Homework } & \multicolumn{2}{|c|}{$\begin{array}{c}\text { Homework as a Primary } \\
\text { Activity }\end{array}$} & \multicolumn{2}{|c|}{$\begin{array}{c}\text { Homework as a Sole } \\
\text { Activity }\end{array}$} \\
\hline & $\begin{array}{l}\text { Female } \\
(1)\end{array}$ & $\begin{array}{l}\text { Male } \\
(2)\end{array}$ & $\begin{array}{c}\text { Female } \\
\text { (3) }\end{array}$ & $\begin{array}{l}\text { Male } \\
(4)\end{array}$ & $\begin{array}{c}\text { Female } \\
(5)\end{array}$ & $\begin{array}{l}\text { Male } \\
(6)\end{array}$ \\
\hline Friday diary & $\begin{array}{l}-5.6210^{* * *} \\
(0.9572)\end{array}$ & $\begin{array}{l}-2.7562 * * * \\
(0.6968)\end{array}$ & $\begin{array}{l}-5.1861 * * * \\
(0.9240)\end{array}$ & $\begin{array}{l}-2.6831^{* * *} \\
(0.6664)\end{array}$ & $\begin{array}{l}-2.6656^{* * *} \\
(0.6299)\end{array}$ & $\begin{array}{l}-1.7202^{* * *} \\
(0.3531)\end{array}$ \\
\hline Saturday diary & & $\begin{array}{l}-1.9452^{* *} \\
(0.8438)\end{array}$ & & $\begin{array}{l}-1.7958 * * \\
(0.8572)\end{array}$ & & $\begin{array}{l}-1.4051 * \\
(0.7753)\end{array}$ \\
\hline Spring interview & $\begin{array}{l}-1.7605^{* *} \\
(0.7740)\end{array}$ & & $\begin{array}{l}-1.8392 * * * \\
(0.7346)\end{array}$ & & $\begin{array}{l}0.0882 \\
(0.6414)\end{array}$ & \\
\hline Weekday precipitation & $\begin{array}{l}-0.0115^{* *} \\
(0.0056)\end{array}$ & & $\begin{array}{l}-0.0115^{* *} \\
(0.0050)\end{array}$ & & $\begin{array}{l}-0.0036 \\
(0.0061)\end{array}$ & \\
\hline $\begin{array}{l}\text { Older than state minimum } \\
\text { driving age }\end{array}$ & & $\begin{array}{l}3.5489 * \\
(1.8730)\end{array}$ & & $\begin{array}{l}3.5157^{*} \\
(1.8603)\end{array}$ & & $\begin{array}{l}0.3418 \\
(0.5561)\end{array}$ \\
\hline Black/Hispanic & $\begin{array}{l}-0.6293 \\
(0.9620)\end{array}$ & $\begin{array}{l}-0.7634 \\
(1.9987)\end{array}$ & $\begin{array}{l}-0.5447 \\
(1.0082)\end{array}$ & $\begin{array}{l}-0.9689 \\
(1.9800)\end{array}$ & $\begin{array}{l}-1.6076 \\
(1.0368)\end{array}$ & $\begin{array}{l}1.4589 * * \\
(0.5849)\end{array}$ \\
\hline Reading score & $\begin{array}{l}0.0082 \\
(0.0322)\end{array}$ & $\begin{array}{l}0.0068 \\
(0.0247)\end{array}$ & $\begin{array}{l}0.0073 \\
(0.0281)\end{array}$ & $\begin{array}{l}0.0140 \\
(0.0250)\end{array}$ & $\begin{array}{l}0.0180 \\
(0.0154)\end{array}$ & $\begin{array}{l}-0.0097 \\
(0.0214)\end{array}$ \\
\hline Applied-problems score & $\begin{array}{l}-0.0125 \\
(0.0374)\end{array}$ & $\begin{array}{l}0.0357 \\
(0.0461)\end{array}$ & $\begin{array}{l}0.0008 \\
(0.0372)\end{array}$ & $\begin{array}{l}0.0248 \\
(0.0491)\end{array}$ & $\begin{array}{l}0.0079 \\
(0.0222)\end{array}$ & $\begin{array}{l}0.0548^{* * *} \\
(0.0210)\end{array}$ \\
\hline $\begin{array}{l}\text { State-mandated college } \\
\text { exam }\end{array}$ & $\begin{array}{l}0.0429 \\
(0.7300)\end{array}$ & $\begin{array}{l}-3.3932 \\
(2.2645)\end{array}$ & $\begin{array}{l}-0.0440 \\
(0.6556)\end{array}$ & $\begin{array}{l}-3.7944 \\
(2.3259)\end{array}$ & $\begin{array}{l}0.3767 \\
(0.7001)\end{array}$ & $\begin{array}{l}-0.1903 \\
(0.8945)\end{array}$ \\
\hline Lives with single mother & $\begin{array}{l}0.5871 \\
(0.9437)\end{array}$ & $\begin{array}{l}1.2181 \\
(1.0895)\end{array}$ & $\begin{array}{l}0.6869 \\
(0.9012)\end{array}$ & $\begin{array}{l}1.2516 \\
(0.9556)\end{array}$ & $\begin{array}{l}0.6145 \\
(0.7938)\end{array}$ & $\begin{array}{l}-0.3805 \\
(1.0015)\end{array}$ \\
\hline $\begin{array}{l}\text { Lives in other family } \\
\text { arrangement }\end{array}$ & $\begin{array}{l}-3.0198 \\
(3.4287)\end{array}$ & $\begin{array}{l}-1.4979 \\
(2.9182)\end{array}$ & $\begin{array}{l}-0.8031 \\
(3.1010)\end{array}$ & $\begin{array}{l}-1.3918 \\
(3.0430)\end{array}$ & $\begin{array}{l}-2.4727 \\
(2.4240)\end{array}$ & $\begin{array}{l}0.6848 \\
(1.0748)\end{array}$ \\
\hline $\begin{array}{l}\text { Number of household } \\
\text { siblings }\end{array}$ & $\begin{array}{l}-0.2238 \\
(0.4614)\end{array}$ & $\begin{array}{l}0.2801 \\
(0.2958)\end{array}$ & $\begin{array}{l}-0.3295 \\
(0.4862)\end{array}$ & $\begin{array}{l}0.3522 \\
(0.2827)\end{array}$ & $\begin{array}{l}0.0934 \\
(0.2437)\end{array}$ & $\begin{array}{l}0.4477 * * \\
(0.1750)\end{array}$ \\
\hline $\begin{array}{l}\text { Household income (in } \\
\$ 1,000 \text { s) }\end{array}$ & $\begin{array}{l}0.0231 * \\
(0.0127)\end{array}$ & $\begin{array}{l}0.0025 \\
(0.0089)\end{array}$ & $\begin{array}{l}0.0220^{*} \\
(0.0122)\end{array}$ & $\begin{array}{l}0.0007 \\
(0.0085)\end{array}$ & $\begin{array}{l}0.0190 * * * \\
(0.0071)\end{array}$ & $\begin{array}{l}0.0031 \\
(0.0075)\end{array}$ \\
\hline $\begin{array}{l}\text { Household income squared } \\
\text { (in } \$ 1,000 \text { s) }\end{array}$ & $\begin{array}{l}-0.0000^{* *} \\
(0.0000)\end{array}$ & $\begin{array}{l}-0.0000 \\
(0.0000)\end{array}$ & $\begin{array}{l}-0.0000 * * \\
(0.0000)\end{array}$ & $\begin{array}{l}0.0000 \\
(0.0000)\end{array}$ & $\begin{array}{l}-0.0000 * * * \\
(0.0000)\end{array}$ & $\begin{array}{l}-0.0000 \\
(0.0000)\end{array}$ \\
\hline Mother college & $\begin{array}{l}3.1389 * * * \\
(1.2016)\end{array}$ & $\begin{array}{l}2.4124^{*} \\
(1.4225)\end{array}$ & $\begin{array}{l}3.2242 * * * \\
(1.1457)\end{array}$ & $\begin{array}{l}1.9315 \\
(1.4498)\end{array}$ & $\begin{array}{l}0.9335 \\
(1.2443)\end{array}$ & $\begin{array}{l}-0.8589 \\
(0.6048)\end{array}$ \\
\hline $\begin{array}{l}\text { Fraction free/reduced-price } \\
\text { lunch }\end{array}$ & $\begin{array}{l}0.2354 \\
(2.0975)\end{array}$ & $\begin{array}{l}0.1598 \\
(1.7464)\end{array}$ & $\begin{array}{l}0.7360 \\
(1.8819)\end{array}$ & $\begin{array}{l}0.6416 \\
(1.8037)\end{array}$ & $\begin{array}{l}0.7846 \\
(1.8357)\end{array}$ & $\begin{array}{l}-0.5711 \\
(1.2163)\end{array}$ \\
\hline Student-teacher ratio & $\begin{array}{l}-0.1163 \\
(0.0809)\end{array}$ & $\begin{array}{l}0.0429 \\
(0.1252)\end{array}$ & $\begin{array}{l}-0.0902 \\
(0.0728)\end{array}$ & $\begin{array}{l}0.0197 \\
(0.1167)\end{array}$ & $\begin{array}{l}0.0579 \\
(0.0972)\end{array}$ & $\begin{array}{l}-0.0612 \\
(0.0526)\end{array}$ \\
\hline Fraction white & $\begin{array}{l}-0.4253 \\
(1.2463)\end{array}$ & $\begin{array}{l}-2.8240 \\
(2.5951)\end{array}$ & $\begin{array}{l}-0.7280 \\
(1.2797)\end{array}$ & $\begin{array}{l}-2.6815 \\
(2.6953)\end{array}$ & $\begin{array}{l}-1.4851 \\
(1.1124)\end{array}$ & $\begin{array}{l}-0.6806 \\
(0.9106)\end{array}$ \\
\hline Observations & 438 & 367 & 438 & 367 & 438 & 367 \\
\hline
\end{tabular}

Notes: Survey weights are used. Standard errors clustered on state are in parentheses. All regressions also include indicators for Census region, year effects, missing WJ-R score indicator, missing school indicator, and a constant. Significance levels: ${ }^{* * *} \mathrm{p}<0.01,{ }^{* *} \mathrm{p}<0.05,{ }^{*} \mathrm{p}<0.1$. 
Table A8. The Effects of Total Homework on Achievement with Controls for Endogeneity (LIML)

(Homework is Modeled as a Tobit)

GPA College Attendance by 20

\begin{tabular}{|c|c|c|c|c|}
\hline & $\begin{array}{c}\text { Female } \\
(\mathrm{N}=438)\end{array}$ & $\begin{array}{c}\text { Male } \\
(\mathrm{N}=367)\end{array}$ & $\begin{array}{c}\text { Female } \\
(\mathrm{N}=438)\end{array}$ & $\begin{array}{c}\text { Male } \\
(\mathrm{N}=367)\end{array}$ \\
\hline & (1) & $(2)$ & (3) & $(4)$ \\
\hline \multicolumn{5}{|l|}{ Panel A. Total Homework } \\
\hline Homework & $\begin{array}{c}0.3663 \\
(0.2620)\end{array}$ & $\begin{array}{c}-0.1792 \\
(0.3185)\end{array}$ & $\begin{array}{c}-0.0032 \\
(0.0048)\end{array}$ & $\begin{array}{c}0.0064 \\
(0.0054)\end{array}$ \\
\hline$\rho$, correlation coefficient & $\begin{array}{l}-0.23 \\
(0.16)\end{array}$ & $\begin{array}{c}0.17 \\
(0.18)\end{array}$ & $\begin{array}{c}0.10 \\
(0.29)\end{array}$ & $\begin{array}{c}0.04 \\
(0.23) \\
\end{array}$ \\
\hline \multicolumn{5}{|c|}{ Panel B. Homework as a Primary Activity } \\
\hline Homework & $\begin{array}{c}0.3753 \\
(0.2582)\end{array}$ & $\begin{array}{c}-0.2267 \\
(0.3093)\end{array}$ & $\begin{array}{c}-0.0058 \\
(0.0051)\end{array}$ & $\begin{array}{c}0.0066 \\
(0.0059)\end{array}$ \\
\hline$\rho$, correlation coefficient & $\begin{array}{l}-0.22 \\
(0.16)\end{array}$ & $\begin{array}{c}0.18 \\
(0.17)\end{array}$ & $\begin{array}{c}0.25 \\
(0.29)\end{array}$ & $\begin{array}{c}0.03 \\
(0.25)\end{array}$ \\
\hline \multicolumn{5}{|c|}{ Panel C. Homework as a Sole Activity } \\
\hline Homework & $\begin{array}{c}0.1315 \\
(0.3915)\end{array}$ & $\begin{array}{c}-0.0455 \\
(0.3813)\end{array}$ & $\begin{array}{c}-0.0083 \\
(0.0062)\end{array}$ & $\begin{array}{c}0.0007 \\
(0.0065)\end{array}$ \\
\hline$\rho$, correlation coefficient & $\begin{array}{c}-0.09 \\
(0.22)\end{array}$ & $\begin{array}{c}0.19 \\
(0.17)\end{array}$ & $\begin{array}{c}0.22 \\
(0.28)\end{array}$ & $\begin{array}{c}0.22 \\
(0.21)\end{array}$ \\
\hline
\end{tabular}

Note: Survey weights are used. Average marginal effects are presented for the probit models. Robust standard errors are in parentheses and are adjusted for clustering on schools. Regressions include all control variables listed in Table 3, and Friday, weekday precipitation, and spring for the female specifications, and Friday, Saturday, and student older than minimum driving age in male specifications as exclusion restrictions in the first-stage homework regressions. Significance levels: $* * * \mathrm{p}<0.01 ; * * \mathrm{p}<0.05 ; * \mathrm{p}<0.10$. 